\title{
The IFRS Option to Reclassify Financial Assets out of Fair Value in 2008: the Roles Played by Regulatory Capital and Too-Important-to-Fail Status
}

\author{
Peter Fiechter, ${ }^{1}$ Wayne R. Landsman, ${ }^{2}$ Kenneth Peasnell, ${ }^{3}$ Annelies Renders ${ }^{4}$
}

May 2017

1. Faculty of Economics and Business, University of Neuchatel, Neuchatel, Switzerland

2. Kenan-Flagler Business School, University of North Carolina at Chapel Hill, Chapel Hill, NC 27599

3. The Management School, Lancaster University, Lancaster, LA1 4YX, UK

4. Maastricht University School of Business and Economics, Maastricht, The Netherlands

We thank Patricia Dechow (editor), two anonymous reviewers, Justin Chircop, Sunhwa Choi, John Gallemore, Thorsten Sellhorn, Christian Stadler, and workshop participants at the Cambridge Financial Accounting Symposium, the EAA Annual Congress, the Joint Workshop of Deutsche Bundesbank and the Research Task Force of the Basel Committee on Banking Supervision for helpful comments. Corresponding author: Wayne Landsman, Kenan-Flagler Business School, University of North Carolina, Chapel Hill, NC 27599-3490, 919-962-3221,wayne_landsman@unc.edu. Annelies Renders acknowledges financial support from the NWO (Veni Research Grant 016.135.086). 


\title{
The IFRS Option to Reclassify Financial Assets out of Fair Value in 2008: the Roles Played by Regulatory Capital and Too-Important-to-Fail Status
}

\begin{abstract}
Amendment of IAS 39 by the IASB in 2008 provided an option to reclassify investments from fair value to historical cost. Whereas this option was available to all firms, it was particularly relevant to banks. We predict that "too important to fail" (TITF) banks took less advantage of this option than non-TITF banks because the political protection they enjoyed insulated them from regulatory pressure. Banks that did not enjoy this protection had greater reason to make use of the option to reclassify since doing so would protect their Tier 1 capital. As predicted, findings reveal that TITF banks made less use of the reclassification option to protect their Tier 1 capital and that there is a significant moderating influence of TITF status on the incentive to reclassify investments for banks with lower regulatory capital. This finding is consistent with TITF banks placing less weight on protecting regulatory capital than non-TITF banks, and thereby retaining flexibility to sell assets. Taken together, our findings provide evidence that accounting choices made by managers are affected by the importance of their firms to the economies in which they are domiciled.
\end{abstract}

Key words: Too Important to Fail, Fair Value Accounting, Bank Regulation, Financial Crisis

JEL codes: G14, G21, G28, M41, M48 


\section{INTRODUCTION}

The accounting policy decision in 2008 by the International Accounting Standards Board (IASB) to permit firms to reclassify retroactively investments from fair value to historical cost categories was one element of a set of policy responses to prevent the collapse of the financial sector. With respect to banks, reclassifying investments had the potential to relieve regulatory pressure and insulate them from exposure to any future losses. Prior research finds that European banks that did reclassify were more likely to be capital constrained than banks that did not. However, many banks that chose not to reclassify were apparently similarly capital constrained as those that reclassified, which suggests that there are other costs and benefits of reclassification that affect banks' accounting choices. For example, two such costs are (i) restrictions on selling assets reclassified to other than fair value categories, and (ii) a foregoing of recognition of any future fair value gains.

We focus in this study on whether the accounting choice to reclassify is affected by whether a bank enjoys protection from intervention by bank regulators (regulatory forbearance) as well as taxpayer protection in the event it requires an injection of capital. Some banks enjoy such protection because they are deemed to be "too big to fail" (TBTF). Other banks enjoy similar protection by virtue of being located in countries where, history suggests, no bank will be allowed to fail, regardless of its size. We label banks that are either TBTF or are domiciled in "no-fail" countries as "too important to fail" (TITF). We hypothesize that because TITF banks were more likely to enjoy taxpayer protection and regulatory forbearance in the event of a regulatory capital shortfall, the incentive in 2008 to reclassify investments to protect regulatory capital was less for TITF than for non-TITF banks.

To address our hypothesis, we examine the reclassification choices for a sample of 160 bank holding companies from 30 European countries in which IFRS is applied. For banks in all such countries, reclassification from the fair value category "held for trading" (HFT) to the cost categories, "loans and receivables" and "held to maturity" (LAR/HTM) brought an immediate benefit of increasing regulatory capital. Whether a bank obtained such a benefit when it reclassified an HFT investment to the "available for sale" (AFS) category depended on whether it was domiciled in one of the 11 countries in which a 
"prudential filter" was applied to losses on AFS debt investments, thereby removing such losses from the primary regulatory capital measure, "Tier 1" capital. If it were one of the 50 banks domiciled in a prudential filter country, it would have an incentive to reclassify from HFT to either AFS or LAR/HTM to avoid recognition of fair value losses when computing its Tier 1 capital. For the 110 banks that were domiciled in the 19 countries in which a prudential filter was not applied, regulatory relief could be obtained only if investments in the fair categories, HFT and AFS, were reclassified to the cost categories,

\section{LAR/HTM.}

To test our prediction that TITF status affected banks' accounting choices to reclassify investments, we utilize each bank's reclassification information, whether it is domiciled in a prudential filter country, the extent of its Tier 1 capital position, and whether it has TITF status. Specifically, we estimate a probit regression in which the dependent variable, RECLASS, takes on the values 0 or 1 . For a bank in a prudential filter country, RECLASS equals 1 if it reclassified a material proportion of investments from HFT to either AFS or LAR/HTM, and 0 otherwise. For a bank in a non-prudential filter country, RECLASS equals 1 if it reclassified a material proportion of investments from either HFT or AFS to LAR/HTM, and 0 otherwise. RECLASS is a composite variable that captures the different ways the three reclassification choices affect regulatory capital, the simultaneity of reclassification choices, and country differences in prudential filters. The key explanatory variables are an indicator variable for whether a bank is a TITF bank, a bank's pre-reclassification level of regulatory capital, and the interaction of TITF with regulatory capital. The TITF measure we employ is intended to reflect the ex ante belief of a bank's managers that the bank enjoys taxpayer protection and regulatory forbearance.

The findings are consistent with our prediction that there is a significant moderating influence of TITF status on the incentive to reclassify investments for banks with lower regulatory capital. Indeed, we find that while a small marginal change in regulatory capital has a between five- and seven-fold decrease in the probability of reclassification for non-TITF banks, there is no effect on the reclassification choice for TITF banks. To focus more directly on the effect of TITF status on the tradeoff banks make between protecting regulatory capital and retaining flexibility to sell assets, we examine the reclassification 
choices made by the subsample of banks from non-prudential filter countries that reclassify out of HFT. We find that TITF banks are more likely to reclassify out of HFT into AFS than non-TITF banks, which is consistent with TITF banks placing more weight on retaining flexibility to sell the assets rather than protecting their regulatory capital.

We conduct additional analyses to address concerns that there are other factors correlated with TITF status that determine the reclassification choice, thereby creating econometric identification problems and threatening the validity of the TITF construct. A primary concern is that TITF and non-TITF banks have different asset compositions. To allow for the possibility that the reclassification choice could be affected by banks' asset compositions, we estimate the probit model including controls for the following: the extent to which banks use derivative assets for hedging purposes; whether they exercise the fair value option for liabilities; the extent to which fair value measurements are based on Level 3, the most subjective measurement category; and the extent of their holdings of crisis-sensitive assets such as assetbacked securities. Our inferences are unaffected by the inclusion of these and other additional variables. Another concern is that because TITF status is, by construction, correlated with bank size, bank size is a correlated omitted variable. We address this concern in two ways. First, we include bank size as a control variable in our probit regressions. Second, to allow for the possibility that the size effect is nonlinear, we estimate our probit model replacing TITF with an indicator variable for whether a bank's assets are above or below the sample median. Findings indicate that the size indicator has neither a direct effect on the reclassification choice nor an indirect effect through the interaction with regulatory capital. A related concern is that because some TITF banks are domiciled in "no-fail" countries, TITF status is correlated with unobserved country-level characteristics. To address this concern, we estimate our probit model including country fixed effects and find that doing so has no effect on our inferences regarding the influence of TITF status on the reclassification choice. A final factor we consider is whether TITF banks chose to protect regulatory capital through loan loss provisioning rather than through reclassification of investments. However, findings reveal that TITF banks did not have smaller discretionary loan loss provisions in 2008 than non-TITF banks. 
Prior research provides evidence that many banks took advantage of the option to reclassify investments retroactively in 2008 to improve their reported regulatory capital. Our study extends this work by providing evidence that TITF status moderated the influence of Tier 1 regulatory capital in affecting a bank's reclassification choices. More importantly, our study provides evidence that accounting choices made by managers of one particular type of firm, banks, are affected by the importance of their firms to the economies in which they are domiciled. In particular, whereas non-TITF banks' accounting choices were largely influenced by regulatory concerns, by virtue of their unique status, TITF banks were relatively free from regulatory concerns when making accounting choices, thereby permitting them to place more weight on retaining flexibility to sell the assets rather than protecting their Tier 1 regulatory capital.

The remainder of the paper is organized as follows. Section 2 describes the institutional background and surveys related literature. Section 3 provides our predictions and estimating equations, and Section 4 describes the data and sample. Section 5 presents our findings, Section 6 provides additional analyses, and Section 7 concludes the study.

\section{INSTITUTIONAL BACKGROUND AND RELATED LITERATURE}

\subsection{Institutional Background}

The origins of the Financial Crisis were numerous and resulted in many policy responses. ${ }^{1}$ The policy response that is relevant to our study resulted from the pressure that was placed on accounting standard setters to make it easier for banks to reduce the probability of regulatory capital violations by simply changing the accounting for financial investments. IAS 39 divides investments into four categories: held for trading (HFT), available for sale (AFS), loans and receivables (LAR), and held to maturity (HTM). HFT securities are measured at fair value, with gains and losses recognized in income

\footnotetext{
${ }^{1}$ The policy fixes included a call for increasing bank capital ratio requirements, restrictions on investments and trading, particularly derivatives, and changes in disclosure requirements.
} 
and hence accumulated in retained earnings. ${ }^{2}$ AFS securities are also measured at fair value, but with gains and losses recognized in other comprehensive income (OCI) and hence retained as a component of accumulated other comprehensive income (AOCI). LAR and HTM are measured at amortized cost, with gains and losses only recognized in income when realized.

The different ways in which fair value gains and losses of investments are treated for accounting purposes can have significant economic effects on banks as a consequence of the way in which regulatory capital is computed under the Basel II Accords (BCBS, 2006). The Basel Accords specify minimum capital requirements that are intended to capture a bank's risk of economic loss. A key regulatory capital requirement is that banks must maintain a specified Tier 1 capital ratio, which is defined as the ratio of Tier 1 capital to risk-weighted assets. ${ }^{3}$

The starting point bank regulators use in determining Tier 1 capital is the book value of common equity and other claims with equity-like features, such as qualifying perpetual preferred stock and minority interest, as defined by the relevant accounting standard setter. Typical adjustments that regulators make to arrive at Tier 1 capital include subtracting unrealized gains on AFS securities, goodwill, and intangible assets. For equity securities, unrealized gains (losses) are always excluded from (included in) the calculation of Tier 1 capital. Whether Tier 1 capital includes losses on AFS debt securities depends on whether the country in which a bank is domiciled applies a prudential filter to unrealized losses on such instruments (CEBS, 2007). In countries in which this prudential filter is applied (i.e., prudential filter countries), unrealized losses are excluded from Tier 1 capital, but they are not

\footnotetext{
${ }^{2}$ There is actually a third category of investments recognized at fair value, namely those investments that a firm elects to recognize at fair value based on application of the fair value option (FVO). As with HFT investments, fair value gains and losses are recognized in income. An important difference between investments in this third category and HFT investments is that the former are precluded by IFRS from being reclassified into AFS or LAR/HTM. Although investments recognized at fair value based on application of the FVO cannot be reclassified, the extent to which a bank makes use of the FVO can, in principle, affect our inferences. We address this issue in section 6.1.

${ }^{3}$ During our sample period and in all our sample countries, the Tier 1 capital ratio had to be at least $4 \%$. In practice, banks typically maintain a target capital position above the required minimum as protection against economic shocks that would reduce their Tier 1 capital below the $4 \%$ level. The Financial Crisis represented an economic shock that was of a magnitude and character that was unprecedented in modern times. In such a situation with heightened volatility and fall in asset prices, bank managers likely changed their beliefs as to what constituted an adequate Tier 1 capital cushion.
} 
excluded in countries in which the prudential filter is not applied (i.e., non-prudential filter countries). Unrealized gains are always excluded regardless of whether the country applies a prudential filter. In all 30 countries in which our sample banks are domiciled, cumulative unrealized gains (losses) on HFT securities increase (decrease) Tier 1 capital. Thus, the way in which investments are classified for financial reporting purposes can have an effect on Tier 1 capital, and hence, can have real economic effects associated with the potential for regulatory intervention.

The accounting rule change introduced by the IASB provided an option for firms to change selectively the accounting measurement basis for investments, which were already permitted under US generally accepted accounting principles (GAAP) in rare circumstances (IASB press release, 13 October 2008). In particular, the IASB amended IAS 39 to give firms the option to reclassify investments across categories by allowing reclassification (i) out of HFT into either LAR or HTM, (ii) out of HFT into AFS, and (iii) out of AFS into either LAR or HTM. The amendment provided for retroactive reclassification, effectively permitting firms to rewrite history during the period between the release of second and fourth quarter 2008 financial statements. Thus, the rule change permitted banks that reclassified investments to appear to be more financially sound, thereby reducing the pressure on politicians to require banks to shore up their finances (Acharya and Ryan, 2016). Although one motivation for the accounting rule change was to relieve pressure on the banking sector, the rule change applied to all firms subject to reporting using IFRS. ${ }^{4}$

There are costs and benefits of reclassifying investments. In prudential filter countries, the primary benefit of reclassifying from HFT to AFS or LAR/HTM that banks obtain is that reclassifications reduce the prospect of future decreases in Tier 1 capital. Other things equal, such reclassifications reduce

\footnotetext{
${ }^{4}$ A similar situation occurred in the US in the 1990s, when pressure from technology firms, primarily in California's Silicon Valley, resulted in the Financial Accounting Standards Board (FASB) changing the requirement to recognize employee stock expense in income. The resulting standard, SFAS 123 (FASB, 1995), which required only disclosure of earnings adjusted for the effects of employee stock option expense, was applicable to all firms, not just those in the technology sector.
} 
regulatory pressure on a bank to improve its Tier 1 capital position in ways it deems to be unnecessarily costly (e.g., selling assets or raising additional equity). An additional benefit stems from the fact that there likely is less pressure to recognize impairments that are detrimental to Tier 1 capital for assets classified as LAR/HTM rather than as HFT or AFS. A bank likely faces greater difficulty convincing its auditor there is no need to recognize an impairment if it is an investment that might be sold before maturity. In non-prudential countries, such benefits only obtain for reclassifications from HFT or AFS to LAR/HTM.

For banks in prudential filter countries, a cost of reclassifying an investment from HFT to LAR/HTM rather than from HFT to AFS is that banks face scrutiny from auditors that might constrain future sales of the reclassified assets. The amended IAS 39, paragraph 50, states that an asset may be reclassified “...if the entity has the intention and ability to hold the financial asset for the foreseeable future or until maturity (IASB 2008a).” IFRS provides no specific guidance regarding what constitutes the foreseeable future, and neither do any of the large international accounting firms. However, in their 2008 annual reports, Deutsche Bank, Deutsche Postbank, and Royal Bank of Scotland indicate that they interpret "foreseeable future" as a one-year period from the reclassification date. In addition, we have been given confidential access to the internal accounting policy manual of a large international bank, which interprets the "foreseeable future" also as a one-year period from the reclassification date. Thus, banks that reclassify investments from HFT to LAR/HTM likely forego the opportunity to benefit by realizing near term future gains from sale. For banks in non-prudential filter countries, there is no regulatory benefit of reclassifying from HFT to AFS and there is the cost of being unable to sell investments in LAR/HTM. ${ }^{5}$

The costs and benefits of reclassifying differ for TITF and non-TITF banks because of their different treatment by the government. Should a particular TITF bank get into difficulty, it can be reasonably confident that the government will bail it out; a non-TITF bank has no such assurance. This potential

\footnotetext{
${ }^{5}$ Although IAS 39 does not define "foreseeable future," it is reasonable to assume that it would have constrained banks that reclassified assets from making sales out of the LAR/HTM in early 2009. We have examined the 2009 financial statements of our sample banks that reclassified investments and found very few appeared to sell investments in 2009. For example, by the middle of 2009, only 4 sample banks had sold or settled investments from any category. Therefore, hindsight does not provide evidence that banks regarded the "foreseeable future" selling constraint as being without force.
} 
injection of taxpayer capital can be viewed as a put option TITF shareholders enjoy, at little or no cost, an option that effectively guarantees that reductions in the value of bank assets will be offset by a corresponding rise in the value of the put option. Hence, TITF banks have an incentive to hold riskier assets than non-TITF banks because the more volatile the assets they hold in their portfolio, the more valuable is the implicit guarantee (Acharya and Steffen, 2015; Lucas and McDonald, 2009; Merton, 1977). In addition, regulators will be more circumspect in pressuring TITF banks to increase their capital, i.e., these banks enjoy greater political protection that results in regulatory forbearance at little or no cost. This benefit they enjoy stems from their relative importance to the health of the overall economy, and consequently their generally greater influence with political policy makers (Goldman et al., 2009).

As a result of their special treatment, TITF banks have less reason to worry about the potential for fair value losses to generate regulatory interventions that might result in their being forced out of business. In contrast to other banks, TITF banks that face financial difficulties are likely to receive taxpayer support in the form of bailouts. This special treatment is not entirely costless. For example, TITF banks that receive such support may face greater scrutiny from regulators, damaging publicity, and senior managers may lose their jobs. However, the benefits of reclassification are likely to be lower for TITF than non-TITF banks because TITF banks enjoy greater regulatory forbearance in the event of a regulatory capital shortfall. Thus, other things equal, TITF banks in prudential filter (non-prudential filter) countries have a lower incentive to reclassify investments out of HFT (HFT or AFS). However, other things may not be equal. In particular, as noted above, TITF banks also have incentives to hold riskier assets, which could have exposed them to greater fair value losses that they might not be willing to recognize. This exposure could offset the otherwise lower incentive to reclassify investments.

\subsection{Related Literature}

Our study examines whether the implicit government support for TITF banks affects accounting choices permitted following the amendment of IAS 39 in 2008. If there was any doubt whether such implicit government support existed, actions by governments around the world in 2008 and 2009 put this 
beyond dispute. ${ }^{6}$ The cost of bank bailouts to state treasuries has been so large as to result in sovereign debt issues that affect most Western economies, including the US, the UK, and the Eurozone generally (Laeven and Valencia, 2010). One major concern long expressed by economists is that the socialization of losses creates incentives for TITF banks to take on more risk than otherwise would be the case (Brewer and Jagtiani, 2007; Kareken and Wallace, 1978; Stern and Feldman, 2009; Wilson and Wu, 2010). ${ }^{7}$ As Admati et al. $(2013,21)$ explains, "Government guarantees that allow banks to enjoy cheap debt financing create numerous distortions and encourage excessive leverage and excessive risk taking."

Consistent with the Admati et al. (2013) observation, banks took increasingly risky loan origination actions and loaded their balance sheets with risky assets that largely were not present even just a decade before the Financial Crisis (e.g., Gorton and Souleles, 2006). These assets included a host of financial instruments, such as mortgage-backed securities that lay at the heart of the Financial Crisis (Gorton, 2010; Landsman et al., 2008), and over-the-counter derivatives. The growth of such financial instruments led accounting standard setters to introduce, over a period of years preceding the Financial Crisis, a series of fair value accounting rule changes that applied to all reporting entities, not just banks. ${ }^{8}$ Banks subsequently lobbied to modify the accounting standards when prices of their assets tumbled in 2008 .

This fall in asset prices caused Tier 1 regulatory capital to become dangerously low (Paananen et al., 2012; Ng and Roychowdhury, 2014). Policy makers were left with the difficult task of how best to increase bank regulatory capital. As noted above, they did so by bailing out banks - providing effectively zero interest loans, and by buying illiquid bank assets through their quantitative easing programs (Laeven

\footnotetext{
${ }^{6}$ Such bailouts took place in many countries. In the US, Congress passed a $\$ 1$ trillion bank bailout that resulted in taxpayer funds being used to prop up America's largest banks including Bank of America, Citibank, and Goldman Sachs. In the UK, Northern Rock was nationalized, and the Royal Bank of Scotland received bailout funds. In many other European countries, notably Ireland, private bank debt was essentially guaranteed by the government.

${ }^{7}$ For example, in the US, TITF banks gambled with taxpayers' money by originating loans to risky borrowers and purchasing asset-backed securities secured by subprime loans (e.g., Gorton and Metrick, 2012; Gorton and Souleles, 2006; Greenspan, 1998).

${ }^{8}$ In the US, such rule changes include recognition of derivatives at fair value (SFAS 133 (FASB, 1998)), a measurement standard for fair value (SFAS 157 (FASB, 2006)), and a standard giving firms the option to measure certain assets at fair value ((SFAS 159 (FASB, 2007)). With minor variations, the IASB largely followed suit by issuing standards.
} 
and Valencia, 2010). Of direct relevance to our study is the fact that banks were also given the opportunity to create the appearance of having sufficient regulatory capital by changing the accounting rules (via an amendment to IAS 39) that affect how regulatory capital is measured. This cosmetic increase in reported regulatory capital reduced pressure on government regulators to act in a way that would have had immediate negative implications for government finances.

Fiechter (2011) and Bischof et al. (2014), using samples of European and worldwide banks applying IFRS, respectively, find that one-third of the banks in both samples took advantage of the opportunity to reclassify investments. Fiechter (2011) finds that among reclassifying banks, the amounts reclassified were, on average, $4 \%$ of total assets and $131 \%$ of the book value of equity. Such reclassification enabled banks to avoid reporting substantial fair value losses, thereby significantly increasing return on assets, return on equity, book value of equity and regulatory capital (Fiechter, 2011) and increasing firm-specific profits by $44 \%$ on average (Bischof et al., 2014). Consistent with the expectation that poorly capitalized banks had incentives to reclassify investments from fair value to amortized cost, for a sample of 101 European banks, Kholmy and Ernstberger (2010) shows that those banks that elected to reclassify investments tend to be large, had experienced a deterioration in profitability and stock prices, and were located in common law countries. Paananen et al. (2012) also examines the determinants of reclassifications by international banks reporting under IFRS and finds that banks with a total regulatory capital ratio that is closer to the country's minimum required ratio and with a larger exposure to fair value measurement are more likely to reclassify. Bischof et al. (2014) highlights that the way in which regulatory capital is defined in a given country, in particular whether the country applies a prudential filter to total regulatory capital (i.e., Tier 1 and Tier 2), affects reclassification choices.

Taken together, these studies provide evidence that banks used the flexibility to reclassify investments provided by the accounting rule change to improve their reported regulatory capital. However, none of these studies examines whether TITF status affected the banks' accounting reclassification choices, particularly whether TITF banks displayed less concern to protect their Tier 1 capital. Our study addresses this question. Furthermore, our dependent variable, RECLASS, reflects the 
different ways the three reclassification choices affect Tier 1 regulatory capital, and allows for both simultaneity of reclassification choices and country differences in the treatment of fair value losses.

\section{PREDICTIONS AND TESTS}

\subsection{Costs and Benefits of Reclassification}

Based on the discussion in Section 2, we develop predictions regarding the effect of a bank's TITF status on its incentives to make accounting policy choices that can affect future net income, asset values, and equity. Some decisions to reclassify bring a certain benefit that Tier 1 capital is protected from any fair value losses associated with retroactive restatement of asset values and any losses that might occur in the future. However, such decisions essentially trade these benefits against the cost of foregone future fair value gains that would enhance Tier 1 capital and income. We begin by providing predictions regarding the costs and benefits of reclassification and how these likely differ for TITF banks. A key assumption underlying our predictions is that a bank knows whether it has TITF status. We base this assumption on the fact that banks have strong connections with both regulators and politicians (Barth et al., 2012), or are domiciled in countries in which no distressed bank previously had been allowed to fail (Demirgüc-Kunt et al., 2008). ${ }^{9}$

Prior to the Financial Crisis, investments that were used by the bank for trading purposes were largely required to be classified as HFT. Discretion principally resided in whether to classify the remaining investments as AFS or LAR/HTM. The decision of how to allocate investments between these two categories reflects the bank's optimal balancing of various costs and benefits identified earlier. ${ }^{10}$

\footnotetext{
${ }^{9}$ Regulators in some countries — in which distressed banks previously had not been allowed to fail— - nevertheless let some banks fail during the financial crisis. For example, this was true in Russia. The critical question is what rational beliefs bank managers were likely to have held when deciding whether to take advantage of the option to reclassify investments. It is thus important to avoid introducing ex post bias by classifying a bank as TITF based on bank failures subsequent to the reclassification decision.

${ }^{10} \mathrm{We}$ assume that bank managers act on behalf of equity investors when making these decisions. That is, with regard to the investment classification decision, we assume there is no substantive goal incongruence between the two groups. Our rationale for this assumption is based on the fact that the compensation of bank managers was largely comprised of bonuses and equity-based instruments (Becher et al., 2005; Chen et al., 2006; Fahlenbrach and
} 
The Financial Crisis altered the relative costs and benefits of classifying investments as HFT, AFS, or LAR/HTM. Asset prices fell markedly and there was a decline in liquidity. The decline in asset values meant that banks would likely face pressure to recognize losses. However, to the extent that banks could claim that declines in value were temporary because of illiquidity of the markets, reclassifying from HFT or AFS to LAR/HTM would reduce these pressures. To see this benefit more clearly, consider the following scenario. A bank purchased an asset for 100 Euros in 2007, which it classified as AFS. During the third quarter of 2008, prices of similar assets declined 40 percent, which suggests the bank should recognize a fair value loss of 40 Euros. If the bank were domiciled (not domiciled) in a prudential filter country, its fair value loss would be recognized but excluded from (included in) Tier 1 capital. If the bank reclassified the asset to LAR/HTM retroactively, the fair value loss would not be recognized, nor would an impairment of the newly classified LAR/HTM asset of 100 Euros be required because the bank could claim to its auditors the apparent loss in value was temporary.

More generally, the costs and benefits of reclassifying investments from the various categories, as highlighted in Figure 1, can be summarized as follows. The cost of reclassifying an investment from HFT or AFS to LAR/HTM is the scrutiny from auditors that might constrain future sales of the reclassified assets, regardless of whether a bank is domiciled in a prudential filter country. For banks in a prudential filter country, there is a benefit of reclassifications from HFT to LAR/HTM or AFS arising from both Tier 1 capital and net income being shielded from losses, and also a benefit of reclassifying from AFS to LAR/HTM arising from comprehensive income being shielded from losses. Banks facing the decision of whether to reclassify HFT securities to AFS or LAR/HTM need to consider the benefit of shielding comprehensive income afforded by the LAR/HTM category but not the AFS category. Even though comprehensive income is not afforded the same prominence as net income, bank managers are likely to be concerned about large losses appearing in comprehensive income. However, for banks in a nonprudential filter country, there is a benefit of reclassifications from HFT to LAR/HTM arising from both

Stulz, 2011). Rather, bank managers and their equity investors are potentially in conflict with regulators and taxpayers. 
Tier 1 capital and net income being shielded from losses, but there is only a net income benefit for the HFT to AFS reclassification; reclassifying from AFS to LAR/HTM shields both Tier 1 capital and comprehensive income from losses.

\section{[Figure 1 here]}

Based on this discussion and findings in prior literature, our first prediction is that, other things equal, the more Tier 1 capital a bank had before the reclassification choice, the more it would be able to absorb fair value losses, and the less its incentive to reclassify investments. Therefore, other things equal, a bank in a prudential filter country with less pre-reclassification Tier 1 regulatory capital is more likely to reclassify investments out of HFT to either AFS or LAR/HTM. Similarly, a low capitalized bank in a non-prudential filter country is more likely to reclassify investments out of either HFT or AFS to

\section{LAR/HTM.}

As noted above, TITF status can affect a bank's reclassification choices. TITF banks are less likely to reclassify away from fair value accounting because TITF banks are insulated from at least some of the costs associated with fair value losses, but enjoy the full benefits of the effects of upward fair value fluctuations on regulatory capital. As a result, we expect the Tier 1 capital effect to be attenuated for TITF banks because they likely enjoy more taxpayer protection and regulatory forbearance than non-TITF banks. In the context of Figure 1, this discussion implies that Tier 1 capital benefits of reclassification are likely to be less for TITF banks; all other costs and benefits are expected, other things equal, to be similar for TITF and non-TITF banks. Thus, our second prediction is that in prudential filter countries, TITF banks with low Tier 1 capital are less likely to reclassify investments out of HFT to either AFS or LAR/HTM than non-TITF banks. Similarly, in non- prudential filter countries, TITF banks with low Tier 1 capital are less likely to reclassify investments out of HFT or AFS or LAR/HTM than non-TITF banks.

\subsection{Empirical Model}


To test our predictions, we develop our empirical model in a way that takes into account two important features that underlie banks' propensity to reclassify investments. The first is whether a bank is domiciled in a prudential filter country. The second is that banks have multiple choices to make depending on the proportions of assets classified in the three investment categories. For example, as described below in section 4, sample banks that reclassify out of HFT to AFS also tend to reclassify out of HFT to LAR/HTM and out of AFS to LAR/HTM. Treating each of these choices independently could result in each of the resulting estimating equations being mis-specified.

To incorporate whether a bank is domiciled in a prudential filter country and to address the simultaneous nature of banks' choices, we estimate a probit regression that expresses a bank's reclassification choice as a function of its regulatory capital position and whether it has TITF status. The dependent variable, RECLASS, takes on the values 0 or 1 :

$$
\text { RECLASS }=\beta^{\prime} X+\varepsilon
$$

We define RECLASS such that it takes into account whether a bank is domiciled in a prudential filter country as follows. For banks in a prudential filter country, RECLASS equals 1 if they reclassify a material proportion of investments from HFT to either AFS or LAR/HTM, and 0 otherwise. ${ }^{11}$ For banks in a non-prudential filter country, RECLASS equals 1 if they reclassify a material proportion of investments from either HFT or AFS to LAR/HTM, and 0 otherwise. In other words, RECLASS distinguishes whether a bank protects its regulatory capital as a result of its reclassification choice. Defining RECLASS as a composite variable enables it to reflect the different ways the three reclassification choices affect regulatory capital, the simultaneity of reclassification choices, and country differences in prudential filters. We select probit because the estimation technique takes into account econometric problems arising from the fact that a substantial proportion of the banks do not reclassify

\footnotetext{
${ }^{11}$ Defining RECLASS in this manner, by design, does not permit us to address the question of why banks in prudential filter counties choose between AFS and LAR/HTM, where, as noted above, the latter category affords protection of comprehensive income from losses.
} 
investments. ${ }^{12}$ We treat the decision to reclassify and if so how much as a latent variable with unknown boundaries concerning the magnitude of the reclassification. As there is no clear a priori way to determine the cutoff boundaries, we use a $5 \%$ materiality criterion for determining cutoff points when estimating the probit model. ${ }^{13}$

The key explanatory variables, $X_{j}$, we use in our probit model are TITF, Pre_Tier1, and TITF Pre_Tier $1 .{ }^{14}$ TITF is an indicator variable that equals 1 for a TITF bank, and 0 otherwise. TITF banks are those that enjoy political protection because of their economic importance to the country in which they are domiciled. In developing our TITF measure, we do not consider whether a sample bank actually received ex post government support because the reclassification choices were based on the bank manager's ex ante belief that the bank has TITF status. Instead, we measure the economic importance of a bank to a particular country in two ways. The first way is based on the ratio of the bank's total assets to the country's GDP at the beginning of 2008. Such banks are of economic importance by virtue of their size relative to their domestic economy. We pool all sample banks and rank them based on this ratio and select those banks in the top $10 \%$ as part of the TITF sample. The $10 \%$ cutoff represents banks with total assets exceeding $75 \%$ of the host country's GDP. This procedure yields 19 banks. ${ }^{15}$ The second way is based on whether a bank is domiciled in a country in which no distressed bank previously had been allowed to fail (Demirgüc-Kunt et al., 2008). All banks in such countries enjoy political protection by virtue of being located in countries where, history suggests, no bank will be allowed to fail, regardless of

\footnotetext{
${ }^{12}$ Inferences do not change when using a logit model instead of a probit model. We also considered, but disregarded, using a linear probability model, because we encountered the difficulty of obtaining fitted probability estimates outside of the $[0,1]$ interval. In particular, although there are no fitted estimates in excess of $1,7 \%$ are less than 0 , with a largest negative value of $-26 \%$. For this reason, all econometric textbooks caution against the use of ordinary least squares estimation when the dependent variable is discrete (see, e.g., Wooldridge (2009), pp. 574-575).

${ }^{13}$ We considered three additional cutoff points: $0 \%, 2.5 \%$, and $10 \%$ of the ex ante HFT and AFS portfolios. Untabulated statistics from analyses based on these other cutoff points result in similar inferences to those based on tabulated findings.

${ }^{14}$ The magnitude of the interaction effect in nonlinear models does not equal the marginal effect of the interaction term. Therefore, we use the Ai and Norton (2003) correction to estimate the magnitude and standard errors of the interaction, TITF Pre_Tierl.

${ }^{15} \mathrm{We}$ also used two cutoff points of 5\%, which reduces the number of such banks from 19 to 10 , and $15 \%$, which increases the number to 33. Estimations of equation (1) based on these alternative cutoff points yield similar inferences to those based on tabulated findings.
} 
its size. ${ }^{16}$ This yields 66 additional TITF banks and introduces heterogeneity into the treatment firms with respect to their size and operations.

Based on our analysis of costs and benefits of reclassification, our first prediction is that the greater is a bank's Tier 1 capital before reclassification, the less likely it is to reclassify its investments. Therefore, we expect the marginal effect of Pre_Tierl to be negative. We measure Tier 1 capital as the ratio of reported Tier 1 capital, after reversing out effects of any reclassifications on Tier 1 capital, to riskweighted assets at the end of 2008, Pre_Tierl. Ideally, we would measure the Tier 1 capital immediately before the reclassification decision is made. However, data limitations preclude us from doing so. ${ }^{17}$ Based on our second prediction that TITF banks with low regulatory capital were less likely to reclassify investments than non-TITF banks with low regulatory capital, we expect the marginal effect of TITF Pre_Tierl to be positive.

We include several control variables when estimating equation (1). The first, Size, which we measure as the natural logarithm of total assets (denominated in million Euros) at the beginning of 2008, is included to mitigate concerns that TITF merely captures bank size, particularly in the case of those TITF banks that are large relative to their host country's GDP. We make no prediction regarding the sign of its coefficient but include it as a general control. ${ }^{18}$ The second, $M B$, is the bank's equity market-to-book ratio as of June 2008, which is the latest date we can identify as predating the reclassification date for all

\footnotetext{
${ }^{16}$ We re-estimated equation (1) eliminating banks in countries where banks were subsequently permitted to fail (e.g., Russian banks). We also re-estimated equation (1) defining TITF banks as either TBTF or domiciled in a nofail country in which no bank was subject to government intervention in 2008. Redefining TITF banks in this way allows for the possibility that bank managers in no fail-countries might have revised their expectations regarding the likelihood of regulatory forbearance when another bank in their country was subject to government intervention in 2008 (e.g., UK and Switzerland). Untabulated findings from both analyses reveal no change in our inferences relative to those based on tabulated findings.

${ }^{17}$ Reclassifications took place in the second half of 2008. This suggests that the best we can do is measure the determinants in June 2008 by using mid-year financial statements. However, doing so would result in a substantial reduction in sample size because either mid-year financial statements are not available or Tier 1 capital disclosures are not included in mid-year financial statements for a substantial number of sample banks. Nonetheless, as a sensitivity analysis, we re-estimated equation (1) using Tier 1 capital as of June 2008, which reduces the sample from 160 to 134 observations. Untabulated findings yield inferences similar to those based on tabulated findings. ${ }^{18}$ In addition to the use of Size as control variable, we allow for the possibility that bank size is nonlinearly related to RECLASS. We re-estimate equation (1) by replacing TITF with an indicator variable for whether a bank's assets are above or below the sample median. Findings from this additional test in Section 6.1 suggest that our inferences are not driven by bank size per se.
} 
sample banks. We include $M B$ to reflect the capital market's perception of the health of a bank (Huizinga and Laeven 2012), which is potentially correlated with TITF and Pre_Tier1. MB could be correlated with TITF because stock prices likely reflect the value of the implicit political protection enjoyed by TITF banks. Also, $M B$ could be correlated with Pre_Tierl because higher capitalized banks are healthier. As with Size, we include $M B$ as a general control and make no prediction regarding the sign of its coefficient. By construction, banks with higher proportions of HFT and AFS assets before the reclassification decision are more likely to reclassify investments from these categories. We therefore include Pre_HFT_TA and Pre_AFS_TA, the ratios of total HFT assets and AFS assets before reclassifications to total assets at the end of 2008 , to control for the possibility that these factors may be correlated with TITF and Pre_Tier1. Data limitations preclude us from measuring Pre_HFT_TA and Pre_AFS_TA in June 2008. To the extent that past profitability is predictive of future profitability, then more profitable banks are less likely to reclassify investments, for reasons unrelated to regulation. Therefore, we include Pre_ROE, return on shareholders' equity for 2008 with the effects of any reclassifications removed from the numerator (net income), deflated by lagged book value of equity. We include indicator variables for whether a bank is a money center bank (Money), a regional bank (Regional), or a savings bank (Savings), to allow for the possibility that such banks have incentives to reclassify unrelated to their TITF status and level of regulatory capital. We also include indicator variables as controls for differences in size of economy (GDPdum), importance of the banking sector (Banks), deposit insurance system (Deposit), and legal environment (Legal) (Demirgüc-Kunt and Detragiache, 2002; Demirgüc-Kunt et al., 2008). ${ }^{19}$ We do not have predictions for the signs of the country-specific variables. In all analyses, we cluster standard errors at the country level.

\section{DATA AND SAMPLE}

We obtain the data used in this study from bank annual reports and from Thomson Reuters. Our basic sample comprises 249 listed bank holding companies from 34 European countries in which IFRS

\footnotetext{
${ }^{19}$ Excluding the country indicator variables does not affect our inferences.
} 
was applied. ${ }^{20,21}$ To be included in our sample, banks had to (i) publish financial statements in English, Dutch, French, German, or Italian, (ii) disclose Tier1 capital ratios and risk-weighted assets, and (iii) hold investments classified in either the HFT or AFS categories in 2008 before reclassification, (iv) be domiciled in a country in which we can determine whether a prudential filter is applied to losses on AFS debt investments. The resulting sample used to estimate equation (1) comprises 160 observations.

Table 1 presents statistics illustrating the relative size of the banking sector in the sample countries, the composition of TITF banks by country, and the relative average sizes of TITF and non-TITF banks. The number of sample banks differs across countries, ranging from 23 in Italy to only one in seven of the smaller countries. Moreover, the importance of the banking sector, as reflected by the ratio of total sample bank assets to GDP, varies substantially across countries: the largest ratios are for Belgium (547\%), Switzerland (459\%), Cyprus (437\%), and the UK (349\%); ${ }^{22}$ the smallest are for Bulgaria (1\%), Latvia (5\%), and Lithuania (6\%). ${ }^{23}$ Table 1 also shows whether or not a country has, as part of a failure resolution, a recent history of permitting at least one bank to fail (Demirgüc-Kunt et al., 2008): 17 (13) countries had at least one (no) bank fail before 2003.

\footnotetext{
${ }^{20}$ IFRS are required to be applied by European entities when preparing consolidated financial statements. In principle, financial statements of a holding company's subsidiaries can be prepared using domestic accounting standards of the countries in which they operate. This raises a question of whether accounting choices by a bank's subsidiaries can differ from those of the holding company and if so, whether this can affect inferences from our tests as they relate to the effect of prudential filter regulations on accounting choices. Although bank subsidiaries are subject to the bank regulations of the country in which they operate, holding companies are subject to the financial reporting and prudential filter rules only of the country in which their consolidated financial statements are filed. A subsidiary bank operating in a country with different prudential filter rules than those its parent company faces, could lead to accounting choices at the subsidiary level being different from those made at the consolidated level. However, capital adequacy only matters at the consolidated level because any actions taken by the holding company to address capital needs at the subsidiary level are eliminated during the consolidation process (IAS 27, paragraph 25 (IASB, 2005)). Therefore, our TITF and prudential filter classifications are unaffected by whether bank holding companies' subsidiaries operate in countries other than the one in which the holding company files financial statements.

${ }^{21}$ In several European countries (e.g., Austria, Denmark, Germany, Hungary, and Norway), banks have the option to use domestic accounting standards instead of IFRS for regulatory reporting. However, none of the banks in our sample uses this option.

${ }^{22}$ The large relative size of the banking sector in several TITF countries raises the question whether the countries could afford to rescue their banks in the event of a systemic failure of the sector. A maintained assumption in this study is that, at the time TITF bank managers were making the reclassification choices, they assumed that they would be rescued in the event of failure. If this maintained assumption does not apply to bank managers in particular countries, predictions regarding the effects of TITF status are less likely to be borne out in our tests.

${ }^{23}$ The banking sector in many countries also includes non-listed banks, which are not included in our sample.
} 


\section{[Table 1 here]}

Table 1 further reveals the distribution of TITF banks across countries. Several countries, including Bulgaria, Croatia, Hungary, Italy, and Poland have no TITF banks. Other countries, including Austria, Belgium, Denmark, France, and Germany have both TITF and non-TITF banks. In these countries, sample banks have their TITF status because of their relative size to the local economy. Finally, in Cyprus, Spain, Sweden, Switzerland, and the United Kingdom, all sample banks are deemed TITF. Table 1 also reveals that 11 (19) sample countries apply (do not apply) a prudential filter to losses on AFS debt investments.

\section{[Table 2 here]}

Table 2 presents sample descriptive statistics showing the simultaneity of reclassification choices. It reveals, for example, that of the 50 banks that reclassified investments from HFT to LAR/HTM, 38\% also reclassified investments from HFT to AFS, and 58\% also reclassified investments from AFS to LAR/HTM. Furthermore, Table 2 also reveals that the simultaneity of reclassification choices applies when there are material reclassifications. For example, of the 33 banks that reclassified material amounts of investments from HFT to LAR/HTM, 24\% also reclassified material amounts of investments from HFT to AFS, and $33 \%$ also reclassified material amounts of investments from AFS to LAR/HTM. These findings underscore the importance of taking into account the simultaneity of the reclassification choices, which is a feature of our constructed dependent variable, RECLASS.

\section{[Table 3 here]}

Table 3, Panel A, presents sample summary statistics for the proportion of reclassified assets, RECLASS, and the independent variables that appear in the probit estimations, partitioned by TITF and 
non-TITF banks. The table reveals that the means of the dependent variable, RECLASS, for the TITF and non-TITF banks, 0.306 and 0.307 , respectively, are insignificantly different. However, this comparison masks the propensities to reclassify investments conditional on regulatory capital as well as other bank characteristics.

On average, TITF banks have lower proportions of pre-reclassification Tier 1 capital than non-TITF banks, i.e., mean (median) values are 0.096 and $0.117(0.086$ and 0.094$) .^{24}$ The two sets of banks differ systematically along other dimensions as well. Notably, TITF banks are larger (mean Size of 10.45 vs. 9.29), and more TITF banks are money center banks (mean Money of $12 \%$ vs. 3\%). In addition, TITF banks are more likely to be domiciled in countries that have a history of taking legal action against bank managers (mean Legal of $13 \%$ vs. 3\%). Regarding the other variables, the differences in means and medians are either insignificant or marginally significant. ${ }^{25}$

Table 3, Panel B, partitions the sample according to whether or not a bank is domiciled in a prudential filter country. The findings reveal that within each regulatory regime, the reclassification behavior for TITF and non-TITF banks is not significantly different. on-TITF banks reclassify at approximately six times the rate in non-prudential filter countries than they do in prudential filter countries, 0.373 vs. 0.063 , and the difference is significant $(t$-statistic $=2.451)$. Although TITF banks also reclassify at a higher rate in non-prudential filter countries than they do in prudential filter countries, 0.353 vs. 0.235 , the difference is insignificant $(t$-statistic $=1.148)$. These findings are consistent with TITF banks being less concerned about the regulatory capital implications of reclassifications than nonTITF banks.

Table 3, Panel C, partitions the sample according to whether a bank's pre-reclassification Tier 1 capital is above or below the sample median. The findings in Panel B reveal there are only marginally significant differences in mean and median RECLASS between TITF and non-TITF banks that have

\footnotetext{
${ }^{24}$ As noted earlier, banks typically maintain Tier 1 capital ratios in excess of the $4 \%$ minimum. The fact that both TITF and non-TITF banks typically had pre-reclassification ratios above $4 \%$ does not imply that bank managers regarded the cushions to be sufficient in the volatile conditions of the Financial Crisis.

${ }^{25}$ Throughout the paper we use a five percent significance level under a one-sided alternative when we have a signed prediction and under a two-sided alternative otherwise.
} 
regulatory capital below the median, i.e., those banks that have greater regulatory capital incentives to reclassify. Likewise, there are no significant differences between the two groups of banks that have regulatory capital above the median. However, more importantly, Panel B's findings also reveal that a bank's regulatory capital position has no significant effect on its reclassification choices only if it is a TITF bank. In particular, the mean and median differences in RECLASS, 0.125 and 0.000 , are insignificantly different from zero $(t$-statistic $=1.239$ and Wilcoxon $z$-statistic $=1.235)$. In contrast, nonTITF banks with lower regulatory capital have significantly higher rates of reclassification. In particular, the mean and median differences in RECLASS, 0.426 and 1.00, are significantly different from zero ( $t$ statistic $=4.414$ and Wilcoxon z-statistic $=3.949)$. The findings in Panel C suggest that the reclassification choices of TITF and non-TITF banks do differ and are consistent with the hypothesis that a bank's regulatory capital position plays a lessor role if it is a TITF bank. Whether this inference can be drawn in a multivariate setting is considered in the next section.

\section{[Table 4 here]}

Table 4 presents sample Pearson (Spearman) correlations below (above) the diagonal. The table reveals that banks that continue to classify investments at fair value tend to have higher Tier 1 capital and to be more profitable. For example, the Pearson correlation coefficients between RECLASS and Pre_Tier1 and between RECLASS and Pre_ROE, -0.212 and -0.162 , respectively, are significantly negative. Although the correlation coefficient between TITF and RECLASS is insignificant, the coefficient between RECLASS and Size, 0.209, is significantly positive. These findings suggest that larger banks tend to be more likely to reclassify and, more importantly, TITF is not merely a proxy for bank size.

\section{FINDINGS}


Table 5, Panel A, presents probit regression summary statistics associated with estimation of equation (1). The table includes coefficients, partial derivatives for $\operatorname{Pr}(R E C L A S S=1)$ with respect to each of the regressors evaluated at sample means, and related heteroscedasticity-robust $z$-statistics.

\section{[Table 5 here]}

The findings in Table 5, Panel A, reveal inferences consistent with our prediction for non-TITF banks. In particular, the coefficient on Pre_Tierl is significantly negative (coefficient $=-27.73 ; z$-statistic $=-2.92$ ) and the marginal effect, i.e., the partial derivative, associated with probability of reclassifying, -7.45 , is significantly negative. This implies that, other things equal, for a non-TITF bank, a small increase in regulatory capital is associated with a seven-fold decrease in the probability of reclassification. Regarding the key interaction variable, TITF Pre_Tierl, its coefficient is significantly positive (coefficient $=22.23, z$-statistic $=2.58)$, and the marginal effect, 5.97 , is also significantly positive. ${ }^{26}$ In addition, untabulated findings from a test for the total coefficient on Pre_Tierl for TITF banks indicate that the sum of Pre_Tierl and TITF Pre_Tierl $(-27.73+22.23)$ is insignificantly different from zero $\left({ }^{2}=1.05 ; \mathrm{p}\right.$-value $\left.=0.31\right)$. These findings indicate that the marginal effect of an increase in regulatory capital is essentially zero for a TITF bank. This contrasts sharply with the greater than seven-fold decrease for non-TITF banks. ${ }^{27}$

\footnotetext{
${ }^{26} \mathrm{Ai}$ and Norton (2003) notes that interpretation of coefficients on interaction variables in non-linear models is problematic. The marginal effects reported in the table are averages of marginal effects evaluated at each data point. The study suggests focusing instead on evaluating marginal effects at points on the distribution, e.g., at the mean or median. Marginal effects evaluated at these two points yield the same inferences as those based on the tabulated averages. More specifically, marginal effects calculated at the median (mean) are 3.79 (5.57), with t-values of 2.45 (2.66).

${ }^{27}$ Another issue relating to the interaction of TITF and Pre_Tierl concerns the possibility that the marginal response of a bank when making its reclassification choice is likely to differ substantially if its regulatory capital is above or below a critical threshold. We therefore estimate an alternative version of equation (1) in which we replace the continuous Pre_Tierl variable with a dichotomous, LOW_Pre_Tierl, that equals one if Pre_Tier 1 capital is below the sample median, and zero otherwise. Untabulated findings reveal that the $L O W \_P r e \_T i e r l$ coefficient is significantly positive (coefficient $=1.279 ; z$-statistic $=4.63$ ), and the marginal effect, 0.350 , is significantly positive $(\mathrm{z}$-statistic $=5.09)$. This finding suggests that non-TITF banks with low regulatory capital are $35 \%$ more likely to reclassify than non-TITF banks with high regulatory capital. In addition, the coefficient on the interaction of TITF
} 
We also estimate versions of equation (1) separately for TITF and non-TITF banks. Doing so eliminates the need to include an interaction between TITF and Pre_Tierl — thereby avoiding complexity of interpretation of its coefficient (Ai and Norton, 2003) — and relaxes the constraint that the coefficients on the control variables are the same for TITF and non-TITF banks. A cost of separate estimations is that there is no direct way to compare coefficients between the models. However, for our purposes, separate estimations permit us to test for significance of the Pre_Tierl coefficient for each of the two groups of banks. Table 5, Panel B, reports findings from estimation of equation (1) separately for TITF and nonTITF banks. For the non-TITF sample, the coefficient on Pre_Tierl is significantly negative (coefficient $=-18.47 ; z$-statistic $=-2.31$, and the marginal effect, -3.88 , is also significantly negative. These findings indicate that the marginal influence of regulatory capital markedly decreases the propensity of non-TITF banks to reclassify. In contrast, for the TITF sample, Panel B of Table 6 reveals that the coefficient on Pre_Tierl is insignificantly different from zero (coefficient $=-4.80 ; z$-statistic $=-0.104)$, and the marginal effect is also insignificantly different from zero. These findings are consistent with there being no influence of Tier 1 capital on the propensity of TITF banks to reclassify. Taken together, these findings are consistent with those presented in Panel A.

Taken together, the findings in Table 5 indicate that pooling together TITF and non-TITF banks when analyzing the impact of regulatory capital on the reclassification choice masks the influence of regulatory capital for both types of banks. There are, of course, other incentives that affect the reclassification choice. Notably, reclassification from either HFT or AFS to LAR/HTM reduces a bank's flexibility to sell the asset before maturity. Because TITF banks have less concern with maintaining their regulatory capital position, other things equal, they stand to benefit by avoiding reclassifying assets to LAR/HTM.

and LOW_Pre_Tierl is significantly positive (coefficient $=1.254 ; z$-statistic $=2.97$ ), and the marginal effect, 0.343 , is significantly negative $(\mathrm{z}$-statistic $=-2.92)$. A test for the sum of the coefficients on LOW_Pre_Tierl and the interaction of TITF and LOW_Pre_Tierl $(+1.279-1.254)$ is insignificantly different from zero $\left(\chi^{2}\right.$-value $=0.00$; p-value $=0.94)$. This finding suggests that TITF banks with low regulatory capital are not more likely to reclassify than TITF banks with high regulatory capital. 


\section{[Table 6 here]}

To focus on the flexibility incentive, we consider an additional test that examines the reclassification behavior of the 43 banks domiciled in non-prudential filter countries that reclassified assets out of HFT to either AFS or LAR/HTM. Reclassifying assets to the AFS category shields income but not regulatory capital; reclassifying assets to the LAR/HTM category shields both income and regulatory capital. Because TITF banks have less reason to worry about their regulatory capital position, they will be more inclined to reclassify from HFT to AFS than from HFT to LAR/HTM, thereby retaining the flexibility to sell assets before maturity. Table 6 , which presents findings from this estimation, reveals that the $T I T F$ coefficient is significantly positive (coefficient $=5.534 ; z$-statistic $=2.53$ ), and the marginal effect, 0.595 , is significantly positive $(\mathrm{z}$-statistic $=4.04)$. This finding suggests that TITF banks are $60 \%$ more likely than non-TITF banks to make the reclassification to the AFS category. Thus, as predicted, reclassifications out of HFT for TITF banks are less likely to be motivated to protect regulatory capital. Such reclassifications instead appear to be motivated to retain the flexibility to sell assets before maturity.

\section{ADDITIONAL ANALYSES}

Although the findings in Tables 5 and 6 are consistent with our predictions, various elements of our research design pose inferential problems that we address in this section; in particular the construct validity of TITF and the possibility that TITF banks used an alternative accounting tool to protect regulatory capital.

\subsection{Identification issues associated with TITF status}

In this sub-section, we address the possibility that there are other factors correlated with TITF status that determine the accounting reclassification choice, thereby creating econometric identification problems and threatening the validity of the TITF construct.

One identification issue is that the extent to which gains on AFS debt securities are excluded from total regulatory capital (i.e., the sum of Tier 1 and Tier 2 capital) in certain countries could affect 
banks' reclassification choices. Following Bischof et al. (2014), we estimate a version of equation (1) that includes a variable that reflects the extent to which AFS gains are excluded from Tier 2 capital. The number of available observations for this analysis is 140 . Untabulated findings indicate that the coefficient on this variable is insignificant (coefficient $=-0.534$; z-statistic $=-0.74$ ) and the coefficients on Pre_Tierl, TITF, and TITF Pre_Tierl are similar in magnitude to those reported in Table 5 and are significant; the coefficients (z-statistics) are $-24.26(-2.89),-1.68(-2.41)$, and $17.76(2.59)$.

A second potential identification problem is that a bank with a greater proportion of Level 3 investments has greater ability to manage its Tier 1 regulatory capital because of the discretion afforded to managers in determining Level 3 fair values. Other things equal, this would suggest that banks with greater proportional holdings of Level 3 investments have less incentive to reclassify. ${ }^{28}$ Thus, if TITF banks hold relatively more investments recognized at fair value measured using unobservable inputs, i.e., Level 3 investments, than non-TITF banks, they will face less incentive to reclassify their investments to LAR/HTM. A third problem is that if TITF banks are more likely than non-TITF banks to hold derivative assets for hedging purposes that are prohibited under IAS 39 from being reclassified from fair value categories to cost categories, they will be unable to reclassify such assets. In addition, to the extent that TITF banks have different risk management strategies than non-TITF banks, these differences likely manifest in their having different net hedging derivative positions. A fourth problem is that the decision to reclassify could be affected by the extent to which a bank held "crisis-sensitive assets," i.e., mortgagebacked securities, collateralized debt obligations, and other related securities that suffered from illiquidity during the financial crisis. A fifth problem is that the decision of a bank whether to reclassify is likely to be affected by whether it has made use of the fair value option for liabilities; recognizing liabilities at fair value could effectively serve as an accounting hedge against fair value gains and losses on assets. ${ }^{29}$

\footnotetext{
${ }^{28}$ On the other hand, it is possible that banks with Level 3 investments might have greater incentive to reclassify such investments because Level 3 assets are less liquid and possibly more risky.

${ }^{29}$ Another identification issue that could affect our inferences regarding the effects of TITF status is the possibility that TITF banks are more likely than non-TITF banks to have unrealized fair value losses from the second to fourth quarter of 2008 that would be directly affected by retroactive reclassifications. Data limitations prevent us from directly addressing this issue because such information is not in the public domain. However, we re-estimated
} 
To address these additional identification problems we include proxy variables for these factors in our estimating equation. In particular, we include two Level 3 variables, the ratios of Level 3 HFT assets and AFS assets to total assets. We measure these ratios as of fiscal-year-end 2009 because disclosure of the fair value hierarchy, i.e., the mix of Level 1, 2, and 3 assets, was not mandated by the IASB's amendment of IFRS 7 before then. We include a variable, the ratio of net hedging derivative position to total assets, which we measure at the beginning of 2008 , the closest measurement date preceding the reclassification date. We include a variable, CRISIS_SENSITIVE, which we measure as the sum of mortgage-backed securities, Alt-A investments, collateralized debt obligations, and leveraged finance products, divided by total assets, with all amounts as of the beginning of 2008. Lastly, we include an indicator variable for whether a bank disclosed in its 2007 fiscal year-end financial statements that it made use of the fair value option for liabilities. Including these four variables results in a reduction of sample banks from 160 to 148 .

Untabulated findings indicate no significant mean differences in the proportions of Level 3 assets to total assets between TITF and non-TITF banks. More specifically, regarding HFT assets, L3_HFT_TA, the mean proportion of Level 3 HFT assets is economically small for both TITF and non-TITF banks, with means of $0.3 \%$ for TITF banks and $0.2 \%$ for non-TITF banks ( $t$-statistic for difference in these means is 0.53). The corresponding mean proportions for AFS assets, $L 3 \_A F S \_T A$, suggest that TITF banks hold an equally small proportion of Level 3 assets as non-TITF banks, $0.4 \%$ vs. $0.4 \%$ ( $t$-statistic $=$ $0.14)$.

Untabulated findings also indicate no significant mean differences in the net hedging derivative positions as a proportion of total assets, NET_HEDGE_TA, between TITF and non-TITF banks. The mean proportion of NET_HEDGE_TA is economically small for both TITF and non-TITF banks, with means of $-0.06 \%$ for TITF banks and $-0.08 \%$ for non-TITF banks ( $t$-statistic for difference in these means is 0.43 ). Other untabulated findings reveal that although the mean ratio of exposure to crisis-

equation (1) including unrealized fair value gains or losses for the full fiscal year 2008. Untabulated findings indicate that the additional variable's coefficient is insignificant and, more importantly, inferences regarding TITF status are the same as those based on the Table 5 findings. 
sensitive assets, CRISIS_SENSITIVE, is larger for non-TITF banks than for TITF banks, $1.21 \%$ vs. $1.08 \%$, the difference is not significantly different $(t$-statistic $=0.176)$. Lastly, untabulated statistics reveal that the proportions of TITF and non-TITF banks exercising the fair value option for liabilities, FVOLdum, $45 \%$ and $29 \%$, are also not significantly different $(t$-statistic $=1.37)$.

Table 7, Panel A, presents findings from estimation of this expanded version of equation (1) that includes the five additional variables. Panel A reveals that the coefficient of $L 3 \_A F S \_T A$ is significantly positive and that the coefficient on $N E T \_H E D G E \_T A$ is significantly negative. More importantly, regarding the identification issue, the coefficients on Pre_Tierl, TITF, and TITF Pre_Tierl are -35.65 , -2.36 , and 22.89, all of which are similar in magnitude to the values from Table 5 and statistically significant. Although inclusion of the additional control variables substantially increases the explanatory power of the model (i.e., pseudo R2 is $35 \%$ compared to $23 \%$ in Table 5), the coefficients on the variables of interest, Pre_Tierl, TITF, and TITF Pre_Tierl, remain remarkably similar. This finding suggests that the additional variables in Table 7 are uncorrelated with the variables of interest, thereby increasing confidence in the inferences we draw.

Another question relating to construct validity of TITF is whether TITF status is an economic feature distinct from bank size. This is a concern because bank size is an element of how we define TITF. Although we control for size when estimating equation (1), it is possible that size is nonlinearly related to RECLASS. To address this issue, we re-estimate equation (1) replacing TITF with an indicator variable, $L A R G E$, that equals one for banks with bank assets exceeding the sample median, and zero otherwise. ${ }^{30}$ Findings presented in Table 7, Panel B, indicate that neither the coefficient on LARGE nor its interaction with Pre_Tierl are different from zero (coefficients $=-0.378$ and $10.499 ; \mathrm{z}$-statistics $=-0.36$ and 0.85 ). These findings are consistent with bank size per se not playing a significant role in a bank's reclassification choice.

A related concern is that because some TITF banks are domiciled in "no-fail" countries, TITF status is correlated with unobserved country-level characteristics. To address this concern, we estimate two

\footnotetext{
${ }^{30}$ Inferences are unchanged when we define $L A R G E$ to include only those banks with assets in the top quartile.
} 
additional probit models. One model includes country fixed effects. The second includes an indicator variable that equals one if a bank is domiciled in a common law country because prior research shows that accounting choices depend on whether firms are domiciled in common or code law countries (Ball et al. 2000; Leuz et al. 2003). ${ }^{31}$ Untabulated findings from these additional estimations reveal that inferences regarding the influence of TITF status on the reclassification choice are the same as those relating to the Table 5 findings.

\subsection{Different kinds of TITF banks}

By construction, TITF is a heterogeneous category that includes TBTF banks domiciled in no-fail countries, TBTF banks domiciled in fail countries, non-TBTF banks domiciled in no-fail countries, and TBTF banks deemed by bank regulators as "globally systemic," regardless of whether they are domiciled in no-fail countries. Ideally, we would treat each of these types of banks differently in our estimations because their incentives to reclassify investments can differ. ${ }^{32}$ However, doing so is precluded by the small sample sizes. For example, as noted earlier, there are only 19 TBTF banks in total, 9 of which are globally systemic. Within these constraints, we repeat our analyses to assess whether our inferences change when some TBTF banks are excluded from the estimations.

\subsubsection{Exclusion of TBTF banks from fail countries}

Because we define a bank as having TITF status either because it is a TBTF bank or is domiciled in a no-fail country, one question is whether our inferences regarding TITF status depend on inclusion of TBTF banks from fail countries. To answer this question, we re-estimate equation (1) excluding the 9 TBTF banks from the TITF sample that are not domiciled in no-fail countries. Untabulated findings indicate that the coefficients on Pre_Tier1, TITF, and TITF Pre_Tier1 are $-24.65,-1.95$, and 19.25, which are similar in magnitude to those reported in Table 5. The coefficients are all significant (zstatistics $=-2.40,-2.17$ and 2.01$)$.

\footnotetext{
${ }^{31} 11 \%$ of our sample banks are domiciled in the common law countries of Cyprus, Ireland, the Netherlands, and the UK.

${ }^{32}$ For example, untabulated statistics reveal the 66 TITF banks that are not TBTF are significantly better capitalized, smaller, and more profitable than the 19 TBTF banks. The fact that the 66 banks are better capitalized and more profitable suggests that they have even less incentive to reclassify investments than the 19 TBTF banks.
} 


\subsubsection{Estimations without SIFI Banks from fail countries}

As noted above, our sample of TITF banks includes banks with global operations. Using the definitional classification based on the list of European banks that were deemed as "Globally Systemically Important Financial Institutions" (SIFI) by the Financial Stability Board (FSB, 2011), we identify 9 SIFI banks that are a subset of the 19 TBTF banks: Dexia, Banco Santander, UBS, HSBC, Credit Agricole, Deutsche Bank, Barclays, Royal Bank of Scotland, and BNP Paribas. Another question is whether the inferences we draw regarding TITF status are largely attributable to the SIFI banks from fail countries. To assess whether this is the case, we re-estimate equation (1) excluding the 6 SIFI banks domiciled in fail countries from the sample of TITF banks. Untabulated findings reveal that as with the Table 5 findings, the coefficients on TITF and Pre_Tierl are significantly negative (coefficients $=-2.04$, -27.98; $z$-statistics $=-2.35,-2.94)$, and the TITF Pre_Tierl coefficient is significantly positive $($ coefficient $=22.23, z$-statistic $=2.47)$. Thus, excluding SIFI banks from fail countries has no effect on our inferences.

\subsection{Did TITF banks provision less for loan losses?}

One plausible alternative explanation for TITF not electing to reclassify investments to protect regulatory capital is that they used other accounting choices that were less costly to use. A prime candidate is discretionary loan loss provisioning. Provisioning is advantageous because loans comprise a larger proportion of most banks' assets and therefore small adjustments can have big effects on regulatory capital positions. In addition, loan loss provisioning is subjective and therefore vulnerable to managerial discretion. In contrast, reclassification is more visible and can be interpreted as a negative signal regarding the bank's financial health. The possibility therefore arises that failure to observe TITF banks reclassifying less than non-TITF banks is attributable not to their lack of concern over regulatory capital but rather because they have a more effective and less costly means of protecting it. If this is the case, then we should observe TITF banks making relatively smaller discretionary loan loss provisions in 2008.

To explore this possibility, we calculate discretionary loan loss provisions for all sample banks in 2008 using the Beatty et al. (2002) methodology. In particular, we use the residuals from a cross-sectional 
regression of the 2008 loan loss provision as a fraction of the average of beginning and ending loans on various determinants of risk of loan loss, including change in non-performing loans and the beginning-ofyear loan loss allowance as a fraction of total loans. Untabulated statistics reveal that mean (median) discretionary loan loss provisions for TITF and non-TITF banks are $0.15 \%(-0.15 \%)$ and $-0.17 \%(-$ $0.28 \%$ ), and that the mean (median) difference between the two groups is significant, with an associated $t$ statistic of $-2.21(-1.98)$. These findings suggest that not only did TITF banks not have smaller discretionary loan loss provisions in 2008, but if anything, they had larger ones. ${ }^{33}$

\section{SUMMARY AND CONCLUDING REMARKS}

In 2008, the IASB permitted banks to reclassify investments retroactively from fair value to cost categories. In this study, we hypothesize that because TITF banks were more likely to enjoy political protection and regulatory forbearance in the event of a regulatory capital shortfall, the incentive to reclassify investments to protect regulatory capital was less for TITF than for non-TITF banks. To test this prediction, we estimate a probit regression using a dependent variable, RECLASS, that is a composite variable that captures the different ways the three reclassification choices affect regulatory capital, the simultaneity of reclassification choices, and country differences in prudential filters. Findings are consistent with the prediction of a moderating influence of TITF status on the incentive to reclassify investments for banks with lower regulatory capital. In particular, we find that while a small marginal change in regulatory capital has a between five- and seven-fold decrease in the probability of reclassification for non-TITF banks, there is no effect on the reclassification choice for TITF banks.

To focus more directly on the effect of TITF status on the tradeoff banks make between protecting regulatory capital and retaining flexibility to sell assets, we examine the accounting reclassification choices made by the subsample of banks from non-prudential filter countries that

\footnotetext{
${ }^{33}$ Furthermore, untabulated statistics relating to total loan loss provisions, i.e., the sum of discretionary and nondiscretionary components, reveal the similar inference that TITF banks did not make smaller loan loss provisions in 2008.
} 
reclassify out of the held-for-trading category. We find that TITF banks are more likely to reclassify out of the held-for-trading category into the available-for-sale category than non-TITF banks, which is consistent with TITF banks placing more weight on retaining flexibility to sell the assets rather than protecting their regulatory capital.

It is difficult to rule out definitively that remaining construct and internal validity issues affect the inferences we draw. There are many differences between TITF banks and non-TITF banks unrelated to bailout incentives that cannot be explored because of sample size limitations. Nonetheless, findings from additional analyses we can conduct indicate that our inferences generally are robust to alternative explanations and estimation techniques.

Taken together, our study's findings provide evidence that accounting choices made by managers are affected by the importance of their firms to the economies in which they are domiciled. In particular, whereas non-TITF banks' accounting choices were largely influenced by regulatory concerns, by virtue of their unique status, TITF banks were relatively free from regulatory concerns when making accounting choices, thereby permitting them to place more weight on retaining flexibility to sell the assets rather than protecting their regulatory capital. 


\section{REFERENCES}

Acharya, V.V., and Ryan, S.G., 2016. Banks' Financial Reporting and Financial System Stability. Journal of Accounting Research, forthcoming.

Acharya, V.V., Steffen, S., 2015. The "greatest" carry trade ever? Understanding Eurozone bank risks. Journal of Financial Economics 115, 215-236.

Admati, A. R., Demarzo, P. M., Hellwig, M. F., Pfleiderer, P., 2013. Fallacies, irrelevant facts, and myths in the discussion of capital regulation: Why bank equity is not expensive. Working paper, Rock Center for Corporate Governance at Stanford University.

Ai, C., Norton, E., 2003. Interaction terms in logit and probit models. Economics Letters 80, 123-129.

Barth, J.R., Caprio Jr., G., Levine, R., 2012. Guardians of Finance: Making Regulators Work for Us, MIT Press: Cambridge, MA.

Ball, R., Kothari, S.P., and Robin., A., 2000. The effect of international institutional factors on properties of accounting earnings. Journal of Accounting \& Economics 29, 1-51.

Basel Committee on Banking Supervision (BCBS), 2006. Basel II: International convergence of capital measurement and capital standards: a revised framework, Comprehensive version, June 2006

Becher, D., Campbell II, T., Frye, M., 2005. Incentive compensation for bank directors: The impact of deregulation. Journal of Business 78, 1753-1777.

Bischof, J., Bruggemann, U., Daske, H., 2014. Fair value reclassifications of financial assets during the financial crisis. Working paper, University of Mannheim.

Brewer III, E., Jagtiani, J., 2007. How much would banks be willing to pay to become 'Too-Big-to-Fail' and to capture other benefits. Federal Reserve Bank of Kansas City Working paper No. 07-05.

Chen, C., Steiner, T., Whyte, A., 2006. Does stock option-based executive compensation induce risktaking? An analysis of the banking industry. Journal of Banking and Finance 30, 915-945.

Committee of European Banking Supervisors (CEBS), 2007. Analytical report on prudential filters for regulatory capital, October.

Demirgüc-Kunt, A., Detragiache, E., 2002. Does deposit insurance increase banking system stability? An empirical investigation. Journal of Monetary Economics 49, 1373-1406.

— Kane, E. J., Laeven, L., 2008. Determinants of deposit-insurance adoption and design. Journal of Financial Intermediation 17, 407-438.

Fahlenbrach, R., Stulz, R., 2011. Bank CEO incentives and the credit crisis. Journal of Financial Economics 99, 11-26.

Fiechter, P., 2011. Reclassification of financial assets under IAS 39: Impact on European banks' financial statements. Accounting in Europe 8, 49-67. 
Financial Accounting Standards Board, 1995. Statement of Financial Accounting Standards (SFAS) No. 123: Accounting for Stock-Based Compensation (Norwalk, CT: FASB).

Financial Accounting Standards Board, 1998. Statement of Financial Accounting Standards (SFAS) No. 133: Accounting for Derivative Instruments and Hedging Activities (Norwalk, CT: FASB).

Financial Accounting Standards Board, 2006. Statement of Financial Accounting Standards (SFAS) No. 157: Fair Value Measurements (Norwalk, CT: FASB).

Financial Accounting Standards Board, 2007. Statement of Financial Accounting Standards (SFAS) No. 159: The Fair Value Option for Financial Assets and Liabilities (Norwalk, CT: FASB).

Financial Stability Board (FSB), 2011. Policy Measures to Address Systemically Important Financial Institutions, November 2011.

Goldman, E., Rocholl, J., So, J., 2009. Do politically connected boards affect firm value? The Review of Financial Studies 22, 2331-2360.

Gorton, G., 2010. Slapped by the Invisible Hand: The Panic of 2007, Oxford: Oxford University Press.

—, Metrick, A., 2012. Securitized banking and the run on repo. Journal of Financial Economics 104, 425-451.

— Souleles, N., 2006. Special Purpose Vehicles and Securitization, in (Stulz R. and Carey M., eds), The Risks of Financial Institutions, 549-597, Chicago: University of Chicago Press.

Greenspan, A. B., 1998. The role of capital in optimal banking supervision and regulation. Federal Reserve Bank of New York Policy Review 4 163Y168.

Huizinga, H., and Laeven, L., 2012. Bank valuation and accounting discretion during a financial crisis. Journal of Financial Economics 106, 614-634.

International Accounting Standards Board (IASB), 2008a. Reclassification of Financial Assets Amendments to IAS 39 Financial Instruments: Recognition and Measurement and IFRS 7 Financial Instruments: Disclosures, Amendment to the Standards, London, October 2008.

— 2008b. Reclassification of Financial Assets - Effective Date and Transition - Amendments to IAS 39 Financial Instruments: Recognition and Measurement and IFRS 7 Financial Instruments: Disclosures, Amendment to the Standards, London, November 2008.

— 2005. Consolidated and Separate Financial Statements, International Accounting Standard 27. London, December 2003.

IASB Press Release, IASB amendments permit reclassification of financial instruments, London, 13 October 2008.

Kareken, J., Wallace, N., 1978. Deposit insurance and bank regulation: A partial-equilibrium exposition. Journal of Business 51, 413-438. 
Kholmy, K., Ernstberger, J., 2010. Reclassification of financial instruments in the financial crisis Empirical evidence from the European banking sector. Working paper, Ruhr-University Bochum.

Laeven, L., Valencia, F., 2010. Resolution of banking crises: The good, the bad, and the ugly. IMF working paper 10/146.

Landsman, W., Peasnell, K., Shakespeare, S., 2008. Are asset securitizations sales or loans? The Accounting Review 83, 1251-1272.

Leuz, C.; D. Nanda; and Wysocki, P., 2003. Earnings management and investor protection: An international comparison. Journal of Financial Economics 69, 505-27.

Lucas, D., McDonald, R., 2009. Valuing government guarantees: Fannie and Freddie revisited. Working paper, Northwestern University.

Merton, R. C., 1977. An analytic derivation of the cost of loan guarantees and deposit insurance: An application of modern option pricing theory. Journal of Banking and Finance 1, 3-11.

Ng, J., Roychowdhury, S., 2014. Do loan loss reserves behave like capital? Evidence from recent bank failures. Review of Accounting Studies 19, 1234-1279.

Paananen, M., Renders, A., Shima, K., 2012. The amendment of IAS 39: Determinants of reclassification behavior and capital market consequences. Journal of Accounting, Auditing and Finance 27, $208-235$.

Stern, G., Feldman, R., 2009. Addressing TITF by shrinking institutions: An initial assessment. The Region, Federal Reserve Bank of Minneapolis.

Wilson, L., Wu, Y. W., 2010. Common (stock) sense about risk-shifting and bank bailouts. Financial Markets and Portfolio Management 24, 3-29.

Wooldridge, J.M., 2009. Introductory Econometrics: A Modern Approach, 4th Edition, Massachusetts: MIT Press. 


\section{FIGURE 1}

\section{Costs and Benefits of Reclassifications}

\section{Prudential filter country}

HFT_to_AFS

AFS_to_LAR/HTM

\section{Non-prudential filter country}

HFT_to_LAR/HTM

HFT_to_AFS

AFS_to_LAR/HTM

\section{$\underline{\text { Costs }}$}

Selling restrictions \& future fair value gains in Tier 1

Future fair value gains in Tier 1

Selling restrictions

\section{$\underline{\text { Costs }}$}

Selling restrictions \& future fair value gains in Tier 1

Future fair value gains in Tier 1

Selling restrictions $\underline{\text { Benefits }}$

Tier $1 \&$ Net income

Tier $1 \&$ Net income

Comprehensive income

Benefits

Tier $1 \&$ Net income

Net income

Tier1 \& Comprehensive income

This figure presents the costs and benefits of the three different reclassification decisions across prudential filter and non-prudential filter countries. HFT, AFS, LAR, and HTM are assets in the category "held for trading", "available for sale", "loans and receivables", and "held to maturity", respectively. In prudential (non-prudential) filter countries, unrealized losses on AFS debt securities are excluded (not excluded) from the calculation of Tier 1 capital. Unrealized gains are always excluded from Tier 1 regardless of whether the country applies a prudential filter or not (CEBS 2007). 
TABLE 1

Country Descriptive Statistics

\begin{tabular}{|c|c|c|c|c|c|c|c|c|c|c|c|}
\hline \multirow[b]{3}{*}{ Country } & \multicolumn{5}{|c|}{ (A): Aggregate country statistics } & \multicolumn{4}{|c|}{ (B): TITF banks } & \multicolumn{2}{|c|}{ (C): Non-TITF banks } \\
\hline & \multirow[b]{2}{*}{$\begin{array}{r}\text { GDP 07 } \\
\text { (million } \\
\text { EUR) } \\
\end{array}$} & \multirow[b]{2}{*}{ Fail History } & \multirow[b]{2}{*}{$\begin{array}{r}\text { Prudential } \\
\text { Filter } \\
\end{array}$} & \multirow[b]{2}{*}{ \# of Banks } & \multirow[b]{2}{*}{$\begin{array}{r}\text { Total Bank } \\
\text { Assets/GDP } \\
\end{array}$} & \multicolumn{2}{|c|}{ TBTF } & \multicolumn{2}{|c|}{ other TITF } & \multirow[b]{2}{*}{$\begin{array}{r}\text { \# of } \\
\text { non-TITF }\end{array}$} & \multirow[b]{2}{*}{$\begin{array}{r}\text { Non-TITF } \\
\text { Assets } \\
\text { GDP }\end{array}$} \\
\hline & & & & & & $\begin{array}{r}\text { \# of } \\
\text { TBTF } \\
\end{array}$ & $\begin{array}{r}\text { TBTF } \\
\text { Assets / } \\
\text { GDP }\end{array}$ & $\begin{array}{r}\text { \# of } \\
\text { other } \\
\text { TITF } \\
\end{array}$ & $\begin{array}{r}\text { other } \\
\text { TITF } \\
\text { Assets / } \\
\text { GDP } \\
\end{array}$ & & \\
\hline Austria & $272^{\prime} 010$ & yes & no & 8 & $141 \%$ & 1 & $74 \%$ & 0 & - & 7 & $10 \%$ \\
\hline Belgium & $335^{\prime} 085$ & yes & yes & 3 & $547 \%$ & 3 & $182 \%$ & 0 & - & 0 & - \\
\hline Bosnia and Herzegovina & $21^{\prime} 759$ & yes & no & 1 & $174 \%$ & 1 & $174 \%$ & 0 & - & 0 & - \\
\hline Bulgaria & $60^{\prime} 185$ & yes & no & 1 & $1 \%$ & 0 & - & 0 & - & 1 & $1 \%$ \\
\hline Croatia & $43^{\prime} 404$ & yes & no & 5 & $64 \%$ & 0 & - & 0 & - & 5 & $13 \%$ \\
\hline Cyprus & $15^{\prime} 879$ & no & no & 3 & $437 \%$ & 2 & $195 \%$ & 1 & $46 \%$ & 0 & - \\
\hline Czech Republic & $132^{\prime} 967$ & yes & yes & 1 & $19 \%$ & 0 & - & 0 & - & 1 & $19 \%$ \\
\hline Denmark & $226^{\prime} 844$ & yes & no & 5 & $212 \%$ & 1 & $198 \%$ & 0 & - & 4 & $3 \%$ \\
\hline Finland & $179^{\prime} 702$ & no & no & 2 & $16 \%$ & 0 & - & 2 & $8 \%$ & 0 & - \\
\hline France & 1'895'284 & yes & yes & 5 & $248 \%$ & 2 & $82 \%$ & 0 & - & 3 & $28 \%$ \\
\hline Germany & $2^{\prime} 432^{\prime} 400$ & yes & no & 14 & $152 \%$ & 1 & $83 \%$ & 0 & - & 13 & $5 \%$ \\
\hline Greece & $226^{\prime} 437$ & no & no & 10 & $153 \%$ & 0 & - & 10 & $15 \%$ & 0 & - \\
\hline Hungary & $100 ' 789$ & yes & no & 2 & $36 \%$ & 0 & - & 0 & - & 2 & $18 \%$ \\
\hline Ireland & $194^{\prime} 083$ & no & yes & 2 & $193 \%$ & 2 & $97 \%$ & 0 & - & 0 & - \\
\hline Italy & 1'546'177 & yes & no & 23 & $148 \%$ & 0 & - & 0 & - & 23 & $6 \%$ \\
\hline Kazakhstan & $72 ' 804$ & no & no & 4 & $44 \%$ & 0 & - & 4 & $11 \%$ & 0 & - \\
\hline Latvia & $21^{\prime} 218$ & yes & no & 1 & $5 \%$ & 0 & - & 0 & - & 1 & $5 \%$ \\
\hline Lithuania & $28 ' 577$ & yes & no & 2 & $6 \%$ & 0 & - & 0 & - & 2 & $3 \%$ \\
\hline Netherlands & $568^{\prime} 664$ & no & yes & 2 & $5 \%$ & 0 & - & 2 & $3 \%$ & 0 & - \\
\hline Norway & $286^{\prime} 143$ & no & yes & 10 & $84 \%$ & 0 & - & 10 & $8 \%$ & 0 & - \\
\hline Poland & $327 ' 262$ & yes & yes & 10 & $39 \%$ & 0 & - & 0 & - & 10 & $4 \%$ \\
\hline Portugal & $168^{\prime} 737$ & no & no & 5 & $125 \%$ & 0 & - & 5 & $25 \%$ & 0 & - \\
\hline Romania & $115^{\prime} 020$ & yes & yes & 1 & $10 \%$ & 0 & - & 0 & - & 1 & $10 \%$ \\
\hline Russia & $926^{\prime} 712$ & no & no & 7 & $28 \%$ & 0 & - & 7 & $4 \%$ & 0 & - \\
\hline Slovakia & $61 ' 547$ & yes & yes & 1 & $15 \%$ & 0 & - & 0 & - & 1 & $15 \%$ \\
\hline Spain & 1'052'730 & no & no & 8 & $168 \%$ & 1 & $87 \%$ & 7 & $12 \%$ & 0 & - \\
\hline Sweden & $330 ' 812$ & no & yes & 5 & $304 \%$ & 1 & $75 \%$ & 4 & $57 \%$ & 0 & - \\
\hline Switzerland & $314 ' 815$ & no & no & 8 & $459 \%$ & 1 & $436 \%$ & 7 & $3 \%$ & 0 & - \\
\hline Turkey & $491^{\prime} 967$ & yes & no & 1 & $9 \%$ & 0 & - & 0 & - & 1 & $9 \%$ \\
\hline United Kingdom & 1'904'621 & no & yes & 10 & $349 \%$ & 3 & $103 \%$ & 7 & $6 \%$ & 0 & - \\
\hline Total & $14 ' 354^{\prime} 632$ & $\begin{array}{r}\text { yes: } 13 \\
\text { no: } 17 \\
\end{array}$ & $\begin{array}{r}\text { yes: } 11 \\
\text { no: } 19 \\
\end{array}$ & 160 & $173 \%$ & 19 & $95 \%$ & 66 & $6 \%$ & 75 & $10 \%$ \\
\hline $\begin{array}{l}\text { This table presents cc } \\
\text { aggregate country statis } \\
\text { big-to-fail ( } T B T F \text { ) or do } \\
\text { percent of all sample ban } \\
\text { Demirgüc-Kunt et al. [2 } \\
\text { capital, and } 0 \text { otherwise }\end{array}$ & $\begin{array}{l}\text { try summary } \\
\text { s, whereas Co } \\
\text { iciled in a cou } \\
\text { and } 0 \text { otherw } \\
\text { 3]), and } 0 \text { oth } \\
\text { urce: CEBS } 2\end{array}$ & $\begin{array}{l}\text { statistics for Eu } \\
\text { lumns (B) and } \\
\text { intry with no } F a \\
\text { vise. Fail Histo } \\
\text { erwise. Pruden } \\
\text { 007). }\end{array}$ & $\begin{array}{l}\text { ean banks wi } \\
\text { show country } \\
\text { History. TBT } \\
\text { is equal to } 1 \text { it } \\
\text { l Filter is eq }\end{array}$ & $\begin{array}{l}\text { ith non-zero ho } \\
\text { y mean statisti } \\
F \text { is equal to } \\
\text { f the respective } \\
\text { ual to } 1 \text { if the }\end{array}$ & $\begin{array}{l}\text { tics for TITF an } \\
1 \text { if the bank's } \\
\text { e country histori } \\
\text { country exclud }\end{array}$ & $\begin{array}{l}\text { Id for trad } \\
\text { TF banks } \\
\text { ets at the } \\
\text {, before } 2 \\
\text { lized fair }\end{array}$ & $\begin{array}{l}\text { ling (HFT } \\
\text {, respecti } \\
\text { beginning } \\
2003 \text { ) let } f \\
\text { values loss }\end{array}$ & $\begin{array}{l}\text { sets ava } \\
\text { bank is } \\
8 \text { relativ } \\
\mathrm{s} \text { as par } \\
\mathrm{FS} \text { deb }\end{array}$ & $\begin{array}{l}\text { ilable for s } \\
\text { defined as } \\
\text { e to its loc } \\
\text { t of failure } \\
\text { t securities }\end{array}$ & $\begin{array}{l}\text { FS). Column } \\
\text { if the bank is } \\
\text { falls whithir } \\
\text { tion (source: } \\
\text { the calculatio }\end{array}$ & $\begin{array}{l}\text { (A) shows } \\
\text { either too- } \\
\text { the top } 10 \\
\text { database of } \\
\text { n of Tier } 1\end{array}$ \\
\hline
\end{tabular}




\section{TABLE 2}

Simultaneity of Reclassifications of European Banks

Overlap of reclassifications (in \%)

$\begin{array}{lllll} & \mathrm{N} & \text { HFT_to_LAR/HTM } & \text { HFT_to_AFS } & \text { AFS_to_LAR/HTM } \\ \text { HFT_to_LAR/HTM } & 50 & - & 38 \% & 58 \% \\ \text { HFT_to_AFS } & 30 & 63 \% & - & 50 \% \\ \text { AFS_to_LAR/HTM } & 42 & 45 \% & 36 \% & -\end{array}$

Overlap of material reclassifications (in \%)

\begin{tabular}{lllll} 
& $\mathrm{N}$ & HFT_to_LAR/HTM & HFT_to_AFS & AFS_to_LAR/HTM \\
HFT_to_LAR/HTM & 33 & - & $24 \%$ & $33 \%$ \\
HFT_to_AFS & 18 & $44 \%$ & - & $11 \%$ \\
AFS_to_LAR/HTM & 32 & $34 \%$ & $6 \%$ & - \\
\hline
\end{tabular}

The table reports the overlap of different (material) reclassification choices. HFT, AFS, LAR, and HTM are assets in the category "held for trading", "available for sale", "loans and receivables", and "held to maturity", respectively. HFT_to_LAR/HTM is an indicator variable equal to 1 if a bank reclassifies out of HFT into LAR or HTM, and 0 otherwise. HFT_to_AFS is an indicator variable equal to 1 if is an indicator variable equal to 1 if a bank reclassifies out of HFT into AFS, and 0 otherwise. $A F S \_t o \_L A R / H T M$ is an indicator variable equal to 1 if a bank reclassifies out of AFS into LAR or HTM. We consider reclassified amounts as material if the proportion of reclassified assets to the ex ante portfolio (i.e., HFT or AFS) is above 5 percent. 


\section{TABLE 3}

Sample Descriptive Statistics

Panel A: Summary statistics for the full sample

\begin{tabular}{|c|c|c|c|c|c|c|}
\hline \multirow[b]{2}{*}{ Variables } & \multicolumn{2}{|c|}{85 TITF Banks } & \multicolumn{2}{|c|}{75 Non-TITF Banks } & \multicolumn{2}{|c|}{ Tests on Differences } \\
\hline & Mean & Median & Mean & Median & $\begin{array}{l}\text { Mean } \\
\text { (t-stat) }\end{array}$ & $\begin{array}{l}\text { Median } \\
\text { (z-stat) }\end{array}$ \\
\hline RECLASS & 0.306 & 0.000 & 0.307 & 0.000 & 0.011 & 0.011 \\
\hline Pre_Tierl & 0.096 & 0.086 & 0.117 & 0.094 & $1.844^{*}$ & 0.792 \\
\hline$M B$ & 1.356 & 1.370 & 1.359 & 1.215 & 0.028 & -0.446 \\
\hline Size & 10.449 & 10.097 & 9.294 & 9.289 & $-3.495 * * *$ & $-3.041 * * *$ \\
\hline Pre_ROE & 0.021 & 0.076 & 0.034 & 0.057 & 0.442 & -0.234 \\
\hline Pre_HFT_TA & 0.093 & 0.036 & 0.108 & 0.046 & 0.628 & 0.074 \\
\hline Pre_AFS_TA & 0.065 & 0.048 & 0.087 & 0.051 & 1.399 & 0.501 \\
\hline GDPdum & 0.518 & 1.000 & 0.667 & 1.000 & $1.921^{*}$ & $1.905^{*}$ \\
\hline Banks & 0.659 & 1.000 & 0.760 & 1.000 & 1.402 & 1.398 \\
\hline Deposit & 0.482 & 0.000 & 0.387 & 0.000 & -1.216 & -1.214 \\
\hline Legal & 0.129 & 0.000 & 0.027 & 0.000 & $-2.402 * *$ & $-2.366^{* *}$ \\
\hline Money & 0.118 & 0.000 & 0.027 & 0.000 & $-2.209 * *$ & $-2.184 * *$ \\
\hline Regional & 0.564 & 1.000 & 0.600 & 1.000 & 0.471 & 0.472 \\
\hline Savings & 0.234 & 0.000 & 0.253 & 0.000 & 0.289 & 0.290 \\
\hline
\end{tabular}

Panel B: Sample partitioning by prudential filter country

\begin{tabular}{|c|c|c|c|c|c|c|}
\hline \multirow{3}{*}{$\begin{array}{l}\text { Prudential filter country } \\
\text { RECLASS }\end{array}$} & \multicolumn{2}{|c|}{34 TITF Banks } & \multicolumn{2}{|c|}{16 Non-TITF Banks } & \multicolumn{2}{|c|}{ Tests on Differences } \\
\hline & Mean & Median & Mean & Median & t-stat & z-stat \\
\hline & 0.235 & 0.000 & 0.063 & 0.000 & -1.486 & -1.469 \\
\hline & & F Banks & 59 Non & ITF Banks & & \\
\hline Non-prudential filter country & Mean & Median & Mean & Median & & \\
\hline RECLASS & 0.353 & 0.000 & 0.373 & 0.000 & 0.215 & 0.216 \\
\hline Tests on Differences & t-stat & z-stat & t-stat & z-stat & & \\
\hline RECLASS & 1.148 & 1.146 & $2.451 * *$ & $2.372 * *$ & & \\
\hline
\end{tabular}


TABLE 3 (continued)

\section{Panel C: Sample partitioning by below and above median Tier 1 capital}

\begin{tabular}{|c|c|c|c|c|c|c|}
\hline \multirow{3}{*}{$\begin{array}{l}\text { Below median Tier } 1 \\
\text { RECLASS }\end{array}$} & \multicolumn{2}{|c|}{47 TITF Banks } & \multicolumn{2}{|c|}{33 Non-TITF Banks } & \multicolumn{2}{|c|}{ Tests on Differences } \\
\hline & Mean & Median & Mean & Median & t-stat & z-stat \\
\hline & 0.362 & 0.000 & 0.545 & 1.000 & 1.637 & 1.621 \\
\hline & \multicolumn{2}{|c|}{38 TITF Banks } & \multicolumn{2}{|c|}{42 Non-TITF Banks } & & \\
\hline Above median Tier 1 & Mean & Median & Mean & Median & & \\
\hline RECLASS & 0.237 & 0.000 & 0.119 & 0.000 & -1.384 & -1.379 \\
\hline Tests on Differences & t-stat & z-stat & t-stat & z-stat & & \\
\hline RECLASS & 1.239 & 1.235 & $4.415 * * *$ & $3.949 * * *$ & & \\
\hline
\end{tabular}

This table presents tests on the differences in means and medians between TITF and non-TITF banks. While Panel A presents test statistics for the full sample, Panel B shows the results when partitioning the sample in prudential filter and nonprudential filter countries. Panel C partitions the sample by banks with below and above median (pre-reclassification) Tier 1 capital. HFT, AFS, LAR, and HTM are assets in the category "held for trading", "available for sale", "loans and receivables", and "held to maturity", respectively.

A bank is defined as TITF if the bank is either too-big-to-fail (TBTF) or domiciled in a country with no Fail History . $T B T F$ is equal to 1 if the bank's total assets at the beginning of 2008 relative to its local GDP falls whithin the top 10 percent of all sample banks, and 0 otherwise. Fail History equals 1 if the respective country historically (i.e., before 2003) let fail banks as part of failure resolution (source: database of Demirgüc-Kunt et al. [2008]), and 0 otherwise.

For a bank in a prudential filter country, RECLASS equals 1 if it reclassified a material proportion of investments from HFT to either AFS or LAR/HTM, and 0 otherwise. For a bank in a non-prudential filter country, RECLASS equals 1 if it reclassified a material proportion of investments from either HFT or AFS to LAR/HTM, and 0 otherwise. We consider reclassified amounts as material if the proportion of reclassified assets to the ex ante portfolio (i.e., HFT or AFS) is above 5 percent.

Pre_Tier1 is the Tier 1 capital ratio excluding any reclassification effects on both Tier 1 capital and risk-weighted assets at the end of 2008. $M B$ is defined as the ratio of market capitalization to book value of equity as of 30 June 2008. Size is defined as the natural logarithm of total assets at the beginning of 2008. Pre_ROE is the net income in 2008 excluding reclassification effects on net income, scaled with book value of equity at the beginning of 2008. Pre_HFT_TA

(Pre_AFS_TA ) is the HFT (AFS) portfolio before reclassifications as a percentage of total assets at the end of 2008. GDPdum is an indicator variable equal to 1 if the GDP of the bank's local country is above the median, and 0 otherwise. Banks is an indicator variable equal to 1 if the number of banks whithin a country is above the sample median, and 0 otherwise. Deposit is an indicator variable equal to 1 if the deposit insurance index by Demirgüc-Kunt and Detragiache (2002) is above the median, and 0 otherwise. Legal is an indicator variable equal to 1 if the bank's local country has at least once taken legal action against bank managers, and 0 otherwise (source: database of Demirgüc-Kunt et al. 2008). Money, Regional, and Savings are sub-industry indicator variables for whether a bank is a money center bank, regional bank, or a savings bank.

$* * *, * *$, and * indicate that the means (medians) are significantly different at the $1 \%, 5 \%$, and $10 \%$ levels, respectively, using a two-sided t-test (Mann-Whitney-Wilcoxon test). 


\section{TABLE 4}

Sample Correlations

\begin{tabular}{|c|c|c|c|c|c|c|c|c|c|c|c|c|c|c|c|}
\hline & {$[1]$} & [2] & [3] & [4] & {$[5]$} & {$[6]$} & {$[7]$} & {$[8]$} & [9] & {$[10]$} & {$[11]$} & [12] & [13] & [14] & [15] \\
\hline [1] RECLASS & 1 & -0.001 & $-0.343 * * *$ & -0.113 & $0.242 * * *$ & $-0.264 * * *$ & $0.336^{* * *}$ & 0.057 & -0.104 & 0.101 & $-0.149^{*}$ & $-0.148^{*}$ & 0.120 & -0.005 & -0.039 \\
\hline [2] TITF & -0.001 & 1 & -0.052 & -0.020 & $0.185^{* *}$ & -0.005 & -0.023 & -0.036 & $-0.199 * *$ & $-0.173 * *$ & 0.061 & $0.208 * * *$ & $0.169^{* *}$ & -0.036 & -0.022 \\
\hline [3] Pre_Tierl & $-0.212^{* * *}$ & $-0.145^{*}$ & 1 & $0.130^{*}$ & $-0.379^{* * *}$ & $0.263^{* * *}$ & $-0.292 * * *$ & -0.028 & 0.070 & $-0.152 * *$ & 0.085 & -0.098 & -0.073 & -0.065 & -0.029 \\
\hline [4] $M B$ & -0.109 & -0.002 & 0.061 & 1 & -0.041 & $0.340 * * *$ & -0.100 & $0.181^{* *}$ & 0.098 & 0.061 & -0.046 & 0.028 & -0.009 & -0.003 & -0.024 \\
\hline [5] Size & $0.209^{* * *}$ & $0.268 * * *$ & $-0.285^{* * *}$ & -0.108 & 1 & -0.069 & $0.505^{* * *}$ & $0.230^{* * *}$ & $0.321^{* * *}$ & 0.062 & $-0.133^{*}$ & $0.153^{* *}$ & $0.216^{* * *}$ & 0.084 & -0.112 \\
\hline [6] $\mathrm{Pre}_{-} \mathrm{ROE}$ & $-0.162 * *$ & -0.035 & 0.106 & $0.229^{* * *}$ & $-0.168^{* *}$ & 1 & $-0.227^{* * * *}$ & -0.009 & -0.031 & $-0.128 *$ & $0.160^{* *}$ & 0.109 & 0.041 & -0.006 & 0.047 \\
\hline [7] Pre_HFT_TA & 0.129 & -0.050 & $-0.169^{* *}$ & -0.055 & $0.431^{* * *}$ & $-0.283^{* * *}$ & 1 & 0.068 & $0.321^{* * *}$ & $0.152^{* * *}$ & -0.030 & 0.027 & $0.160^{* *}$ & -0.028 & -0.013 \\
\hline [8]Pre_AFS_TA & 0.064 & -0.111 & 0.123 & $0.136^{*}$ & $0.146^{*}$ & -0.098 & $0.160 * *$ & 1 & $0.132^{*}$ & -0.101 & $-0.149 *$ & $0.254 * * *$ & 0.104 & 0.104 & $-0.177^{* *}$ \\
\hline [9] GDPdum & -0.104 & $-0.151^{*}$ & 0.065 & 0.078 & $0.311^{* * *}$ & -0.083 & $0.248 * * *$ & 0.124 & 1 & $0.383^{* * *}$ & $-0.253^{* * *}$ & 0.126 & 0.034 & 0.084 & $-0.217 * * *$ \\
\hline [10] Banks & 0.101 & -0.111 & 0.020 & 0.020 & -0.008 & -0.083 & 0.010 & -0.133 & $0.324 * * *$ & 1 & $-0.369 * * *$ & -0.116 & -0.033 & -0.115 & 0.105 \\
\hline [11] Deposit & $-0.149^{*}$ & 0.096 & -0.037 & -0.018 & $-0.176^{* *}$ & 0.107 & -0.079 & -0.044 & $-0.310^{* * *}$ & $-0.455^{* * *}$ & 1 & $0.257 * * *$ & -0.111 & -0.053 & $0.190^{* *}$ \\
\hline [12] Legal & $-0.148^{*}$ & $0.188^{* *}$ & -0.072 & 0.048 & $0.227^{* * * *}$ & 0.004 & 0.046 & $0.326 * * *$ & 0.126 & -0.116 & $0.257 * * *$ & 1 & 0.058 & 0.112 & $-0.136^{*}$ \\
\hline [13] Money & 0.120 & $0.172 * *$ & -0.073 & 0.012 & $0.271 * * *$ & -0.055 & $0.153^{* *}$ & 0.037 & 0.034 & -0.033 & -0.111 & 0.058 & 1 & $-0.339 * * *$ & $-0.163^{* *}$ \\
\hline [14] Regional & -0.005 & -0.048 & $-0.136^{*}$ & 0.010 & 0.029 & 0.093 & -0.080 & 0.027 & 0.084 & -0.115 & -0.053 & 0.112 & $-0.339 * * *$ & 1 & $-0.665^{* * * *}$ \\
\hline [15] Savings & -0.039 & -0.007 & 0.011 & -0.073 & -0.104 & 0.045 & -0.030 & -0.124 & $-0.217^{* * *}$ & 0.105 & $0.189^{* *}$ & $-0.136^{*}$ & $-0.163^{* *}$ & $-0.665 * * *$ & 1 \\
\hline
\end{tabular}

This table reports pearson (spearman) correlations below (above) the diagonal. See Table 3 for the definition of the variables. ***, **, and * indicate statistical significance at the $1 \%, 5 \%$, and $10 \%$ levels (two-sided). 
TABLE 5

Results of Probit Regression

\section{Panel A: Full sample}

\section{Dependent variable: $R E C L A S S$}

\begin{tabular}{|c|c|c|c|}
\hline Variables & Predicted sign & $\begin{array}{l}\text { Coefficient } \\
(z \text {-stat })\end{array}$ & $\begin{array}{l}\text { Marginal effects } \\
(z \text {-stat })\end{array}$ \\
\hline TITF & - & $\begin{array}{l}-2.057 * * \\
(-2.53)\end{array}$ & $\begin{array}{l}-0.553 * * \\
(-2.50)\end{array}$ \\
\hline Pre_Tierl & - & $\begin{array}{l}-27.726 * * * \\
(-2.92)\end{array}$ & $\begin{array}{l}-7.451 * * * \\
(-3.05)\end{array}$ \\
\hline TITF $x$ Pre_Tierl & + & $\begin{array}{l}22.226 * * * \\
(2.58)\end{array}$ & $\begin{array}{l}5.973 * * \\
(2.51)\end{array}$ \\
\hline$M B$ & $?$ & $\begin{array}{l}-0.143 \\
(-0.82)\end{array}$ & $\begin{array}{l}-0.038 \\
(-0.81)\end{array}$ \\
\hline Size & $?$ & $\begin{array}{l}0.148 * \\
(1.89)\end{array}$ & $\begin{array}{l}0.040 * * \\
(1.97)\end{array}$ \\
\hline Pre_ROE & - & $\begin{array}{l}-0.209 \\
(-0.33)\end{array}$ & $\begin{array}{l}-0.056 \\
(-0.33)\end{array}$ \\
\hline Pre_HFT_TA & + & $\begin{array}{l}-0.232 \\
(-0.25)\end{array}$ & $\begin{array}{l}-0.062 \\
(-0.25)\end{array}$ \\
\hline Pre_AFS_TA & + & $\begin{array}{l}3.692 * * \\
(2.30)\end{array}$ & $\begin{array}{l}0.992 * * \\
(2.41)\end{array}$ \\
\hline GDPdum & $?$ & $\begin{array}{l}-0.662 * * \\
(-1.99)\end{array}$ & $\begin{array}{l}-0.178 * * \\
(-2.17)\end{array}$ \\
\hline Banks & $?$ & $\begin{array}{l}0.574 \\
(1.49)\end{array}$ & $\begin{array}{l}0.154 \\
(1.50)\end{array}$ \\
\hline Deposit & $?$ & $\begin{array}{l}0.164 \\
(0.40)\end{array}$ & $\begin{array}{l}0.044 \\
(0.40)\end{array}$ \\
\hline Legal & $?$ & $\begin{array}{l}-1.781 * * \\
(-2.10)\end{array}$ & $\begin{array}{l}-0.479 * * \\
(-2.13)\end{array}$ \\
\hline Money & $?$ & $\begin{array}{l}0.152 \\
(0.38)\end{array}$ & $\begin{array}{l}0.041 \\
(0.37)\end{array}$ \\
\hline Regional & $?$ & $\begin{array}{l}-0.150 \\
(-0.47)\end{array}$ & $\begin{array}{l}-0.040 \\
(-0.48)\end{array}$ \\
\hline Savings & $?$ & $\begin{array}{l}-0.432 \\
(-0.87)\end{array}$ & $\begin{array}{l}-0.116 \\
(-0.89)\end{array}$ \\
\hline Constant & & $\begin{array}{l}0.648 \\
(0.39)\end{array}$ & \\
\hline Pseudo-R2 & & $23 \%$ & \\
\hline Observations & & 160 & \\
\hline
\end{tabular}


TABLE 5 (continued)

Panel B: Split regressions partitioned by TITF

(A): TITF banks

(B): Non-TITF banks

Dependent variable: $R E C L A S S$

\begin{tabular}{|c|c|c|c|c|c|c|}
\hline Variables & $\begin{array}{c}\text { Predicted } \\
\text { sign } \\
\end{array}$ & $\begin{array}{l}\text { Coefficient } \\
(z \text {-stat })\end{array}$ & $\begin{array}{l}\text { Marginal } \\
\text { effects }\end{array}$ & $\begin{array}{c}\text { Predicted } \\
\text { sign } \\
\end{array}$ & $\begin{array}{l}\text { Coefficient } \\
(z \text {-stat })\end{array}$ & $\begin{array}{l}\text { Marginal } \\
\text { effects }\end{array}$ \\
\hline Pre_Tierl & $?$ & $\begin{array}{l}-4.797 \\
(-1.04)\end{array}$ & $\begin{array}{l}-1.359 \\
(-1.13)\end{array}$ & - & $\begin{array}{l}-18.471 * * \\
(-2.31)\end{array}$ & $\begin{array}{l}-3.879 * * \\
(-2.22)\end{array}$ \\
\hline$M B$ & $?$ & $\begin{array}{l}-0.434 * \\
(-1.87)\end{array}$ & $\begin{array}{l}-0.123^{*} \\
(-1.65)\end{array}$ & $?$ & $\begin{array}{l}0.280 \\
(0.91)\end{array}$ & $\begin{array}{l}0.059 \\
(0.93)\end{array}$ \\
\hline Size & $?$ & $\begin{array}{l}0.142 \\
(1.05)\end{array}$ & $\begin{array}{l}0.040 \\
(1.05)\end{array}$ & $?$ & $\begin{array}{l}0.249 * * \\
(2.23)\end{array}$ & $\begin{array}{l}0.052 * * \\
(2.21)\end{array}$ \\
\hline Pre_ROE & - & $\begin{array}{l}1.857 * \\
(1.79)\end{array}$ & $\begin{array}{l}0.526 * \\
(1.96)\end{array}$ & - & $\begin{array}{l}-3.355^{* *} \\
(-2.20)\end{array}$ & $\begin{array}{l}-0.705 * * \\
(-2.47)\end{array}$ \\
\hline Pre_HFT_TA & + & $\begin{array}{l}-0.914 \\
(-0.37)\end{array}$ & $\begin{array}{l}-0.259 \\
(-0.37)\end{array}$ & + & $\begin{array}{l}0.058 \\
(0.04)\end{array}$ & $\begin{array}{l}0.012 \\
(0.04)\end{array}$ \\
\hline Pre_AFS_TA & + & $\begin{array}{l}2.244 \\
(0.67)\end{array}$ & $\begin{array}{l}0.636 \\
(0.71)\end{array}$ & + & $\begin{array}{l}1.010 \\
(0.49)\end{array}$ & $\begin{array}{l}0.212 \\
(0.47)\end{array}$ \\
\hline GDPdum & $?$ & $\begin{array}{l}-1.099 * * \\
(-2.29)\end{array}$ & $\begin{array}{l}-0.311 * * * \\
(-3.01)\end{array}$ & $?$ & $\begin{array}{l}-0.583 \\
(-1.39)\end{array}$ & $\begin{array}{l}-0.123 \\
(-1.34)\end{array}$ \\
\hline Deposit & $?$ & $\begin{array}{l}-0.423 \\
(-0.93)\end{array}$ & $\begin{array}{l}-0.120 \\
(-0.89)\end{array}$ & $?$ & $\begin{array}{l}-0.314 \\
(-0.43)\end{array}$ & $\begin{array}{l}-0.066 \\
(-0.44)\end{array}$ \\
\hline Regional & $?$ & $\begin{array}{l}-0.459 \\
(-1.30)\end{array}$ & $\begin{array}{l}-0.130 \\
(-1.36)\end{array}$ & $?$ & $\begin{array}{l}-0.811 \\
(-1.37)\end{array}$ & $\begin{array}{l}-0.170 \\
(-1.46)\end{array}$ \\
\hline Savings & $?$ & $\begin{array}{l}-0.502 \\
(-1.22)\end{array}$ & $\begin{array}{l}-0.142 \\
(-1.26)\end{array}$ & $?$ & $\begin{array}{l}-1.009 \\
(-1.45)\end{array}$ & $\begin{array}{l}-0.212^{*} \\
(-1.68)\end{array}$ \\
\hline Constant & & $\begin{array}{l}-0.033 \\
(-0.02)\end{array}$ & & & $\begin{array}{l}-0.307 \\
(-0.20)\end{array}$ & \\
\hline $\begin{array}{l}\text { Pseudo-R2 } \\
\text { Observations }\end{array}$ & & $\begin{array}{l}19 \% \\
85\end{array}$ & & & $\begin{array}{l}39 \% \\
75\end{array}$ & \\
\hline
\end{tabular}

(continued) 


\section{TABLE 5 (continued)}

This table reports probit coefficient estimates, marginal effects, and z-statistics based on robust standard errors clustered at the country level in parentheses. HFT, AFS, LAR, and HTM are assets in the category "held for trading", "available for sale", "loans and receivables", and "held to maturity", respectively. Panel A reports the results for the full sample, while Panel B presents the results for TITF and non-TITF banks separately. For a bank in a prudential filter country, RECLASS equals 1 if it reclassified a material proportion of investments from HFT to either AFS or LAR/HTM, and 0 otherwise. For a bank in a non-prudential filter country, RECLASS equals 1 if it reclassified a material proportion of investments from either HFT or AFS to LAR/HTM, and 0 otherwise. We consider reclassified amounts as material if the proportion of reclassified assets to the ex ante portfolio (i.e., HFT or AFS) is above 5 percent.

A bank is defined as TITF if the bank is either too-big-to-fail (TBTF) or domiciled in a country with no Fail History. TBTF is equal to 1 if the bank's total assets at the beginning of 2008 relative to its local GDP falls whithin the top 10 percent of all sample banks, and 0 otherwise. Fail History equals 1 if the respective country historically (i.e., before 2003) let fail banks as part of failure resolution (source: database of Demirgüc-Kunt et al. [2008]), and 0 otherwise. Pre_Tierl is the Tier 1 capital ratio excluding any reclassification effects on both Tier 1 capital and risk-weighted assets at the end of 2008 . TITF $x$ Pre_Tierl is an interaction term between TITF and Pre_Tierl .

$M B$ is defined as the ratio of market capitalization to book value of equity as of 30 June 2008. Size i defined as the natural logarithm of total assets at the beginning of 2008. Pre_ROE is the net income in 2008 excluding reclassification effects on net income, scaled with book value of equity at the beginning of 2008. Pre_HFT_TA (Pre_AFS_TA) is the HFT (AFS) portfolio before reclassifications as a percentage of total assets at the end of 2008. Money, Regional, and Savings are sub-industry indicator variables for whether a bank is a money center bank, regional bank, or a savings bank. GDPdum is an indicator variable equal to 1 if the GDP of the bank's local country is above the median, and 0 otherwise. Banks i an indicator variable equal to 1 if the number of banks whithin a country is above the sample median, and 0 otherwise. Deposit is an indicator variable equal to 1 if the deposit insurance index by Demirguic-Kunt and Detragiache (2002) is above the median, and 0 otherwise. Legal is an indicator variable equal to 1 if the bank's local country has at least once taken legal action against bank managers, and 0 otherwise (source: database of Demirguic-Kunt et al. 2008).

$* * *, * *$, and $*$ indicate statistical significance at the $1 \%, 5 \%$, and $10 \%$ levels (two-sided). 


\section{TABLE 6}

Held for Trading (HFT) to Available for Sale (AFS) Reclassifications in Non-prudential Filter Countries

\section{Dependent variable: Reclassification from HFT to AFS but not to LAR/HTM}

\begin{tabular}{|c|c|c|c|}
\hline Variables & Predicted sign & $\begin{array}{l}\text { Coefficient } \\
\text { (z-stat) }\end{array}$ & $\begin{array}{l}\text { Marginal effects } \\
(z \text {-stat })\end{array}$ \\
\hline$T I T F$ & - & $\begin{array}{l}5.534 * * \\
(2.53)\end{array}$ & $\begin{array}{l}0.595 * * * \\
(4.04)\end{array}$ \\
\hline$M B$ & $?$ & $\begin{array}{l}2.565 \\
(1.62)\end{array}$ & $\begin{array}{l}0.276 * * \\
(2.28)\end{array}$ \\
\hline Size & $?$ & $\begin{array}{l}-0.501 * * * \\
(-4.50)\end{array}$ & $\begin{array}{l}-0.054 * * * \\
(-2.98)\end{array}$ \\
\hline Pre_ROE & - & $\begin{array}{l}-1.463 \\
(-0.45)\end{array}$ & $\begin{array}{l}-0.157 \\
(-0.48)\end{array}$ \\
\hline Pre_HFT_TA & + & $\begin{array}{l}3.829 \\
(1.01)\end{array}$ & $\begin{array}{l}0.412 \\
(1.05)\end{array}$ \\
\hline Pre_AFS_TA & + & $\begin{array}{l}-40.272 * \\
(-1.96)\end{array}$ & $\begin{array}{l}-4.328 * * * \\
(-3.23)\end{array}$ \\
\hline GDPdum & $?$ & $\begin{array}{l}-5.645^{*} \\
(-1.88)\end{array}$ & $\begin{array}{l}-0.607 * * * \\
(-3.03)\end{array}$ \\
\hline Banks & $?$ & $\begin{array}{l}-0.691 \\
(-0.92)\end{array}$ & $\begin{array}{l}-0.074 \\
(-1.02)\end{array}$ \\
\hline Deposit & $?$ & $\begin{array}{l}-0.261 \\
(-0.21)\end{array}$ & $\begin{array}{l}-0.028 \\
(-0.21)\end{array}$ \\
\hline Constant & & $\begin{array}{l}-1.377 \\
(-0.35)\end{array}$ & \\
\hline $\begin{array}{l}\text { Pseudo-R2 } \\
\text { Observations }\end{array}$ & & $\begin{array}{l}60 \% \\
43\end{array}$ & \\
\hline
\end{tabular}

This table reports probit coefficient estimates, marginal effects, and $z$-statistics based on robust standard errors clustered at the country level in parentheses. HFT, AFS, LAR, and HTM are assets in the category "held for trading", "available for sale", "loans and receivables", and "held to maturity", respectively. The sample includes banks from non-prudential filter countries that reclassify out of HFT. The dependent variable equals 1 (0) if the bank reclassifies from HFT to AFS (HFT to LAR/HTM).

A bank is defined as TITF if the bank is either too-big-to-fail (TBTF) or domiciled in a country with no Fail History. TBTF is equal to 1 if the bank's total assets at the beginning of 2008 relative to its local GDP falls whithin the top 10 percent of all sample banks, and 0 otherwise. Fail History equals 1 if the respective country historically (i.e., before 2003) let fail banks as part of failure resolution (source: database of Demirguic-Kunt et al. [2008]), and 0 otherwise. See Table 3 for the definition of the other variables.

$* * *, * *$, and $*$ indicate statistical significance at the $1 \%, 5 \%$, and $10 \%$ levels (two-sided). 


\section{TABLE 7}

Fair Value Controls and Bank Size

\section{Panel A: Probit regression with fair value controls}

Dependent variable: $R E C L A S S$

\begin{tabular}{|c|c|c|c|}
\hline Variables & Predicted sign & $\begin{array}{l}\text { Coefficient } \\
(z-\text { stat })\end{array}$ & $\begin{array}{l}\text { Marginal effects } \\
(z-s t a t)\end{array}$ \\
\hline TITF & - & $\begin{array}{l}-2.360 * * \\
(-2.28)\end{array}$ & $\begin{array}{l}-0.523 * * \\
(-2.23)\end{array}$ \\
\hline Pre_Tierl & - & $\begin{array}{l}-35.651 * * * \\
(-2.78)\end{array}$ & $\begin{array}{l}-7.899 * * * \\
(-2.85)\end{array}$ \\
\hline TITF $x$ Pre_Tierl & + & $\begin{array}{l}22.889 * * \\
(1.99)\end{array}$ & $\begin{array}{l}5.071 * * \\
(2.00)\end{array}$ \\
\hline$M B$ & $?$ & $\begin{array}{l}-0.178 \\
(-0.79)\end{array}$ & $\begin{array}{l}-0.040 \\
(-0.79)\end{array}$ \\
\hline Size & $?$ & $\begin{array}{l}0.232 * * * \\
(2.98)\end{array}$ & $\begin{array}{l}0.051 * * * \\
(3.03)\end{array}$ \\
\hline Pre_ROE & - & $\begin{array}{l}0.180 \\
(0.22)\end{array}$ & $\begin{array}{l}0.040 \\
(0.22)\end{array}$ \\
\hline Pre_HFT_TA & + & $\begin{array}{l}0.555 \\
(0.48)\end{array}$ & $\begin{array}{l}0.123 \\
(0.49)\end{array}$ \\
\hline Pre_AFS_TA & + & $\begin{array}{l}4.996 * * \\
(2.53)\end{array}$ & $\begin{array}{l}1.107 * * * \\
(2.65)\end{array}$ \\
\hline GDPdum & $?$ & $\begin{array}{l}-0.888 * * \\
(-2.02)\end{array}$ & $\begin{array}{l}-0.197 * * \\
(-2.06)\end{array}$ \\
\hline Banks & $?$ & $\begin{array}{l}0.414 \\
(0.95)\end{array}$ & $\begin{array}{l}0.092 \\
(0.95)\end{array}$ \\
\hline Deposit & $?$ & $\begin{array}{l}0.269 \\
(0.61)\end{array}$ & $\begin{array}{l}0.059 \\
(0.60)\end{array}$ \\
\hline Legal & $?$ & $\begin{array}{l}-3.375 * * * \\
(-3.60)\end{array}$ & $\begin{array}{l}-0.748 * * * \\
(-3.81)\end{array}$ \\
\hline Money & $?$ & $\begin{array}{l}-0.352 \\
(-0.79)\end{array}$ & $\begin{array}{l}-0.078 \\
(-0.82)\end{array}$ \\
\hline Regional & $?$ & $\begin{array}{l}-0.946 * * * \\
(-2.91)\end{array}$ & $\begin{array}{l}-0.210 * * * \\
(-3.38)\end{array}$ \\
\hline Savings & $?$ & $\begin{array}{l}-1.233 * * \\
(-2.30)\end{array}$ & $\begin{array}{l}-0.273 * * \\
(-2.49)\end{array}$ \\
\hline L3_HFT_TA & $?$ & $\begin{array}{l}-36.351 \\
(-0.84)\end{array}$ & $\begin{array}{l}-8.054 \\
(-0.86)\end{array}$ \\
\hline L3_AFS_TA & $?$ & $\begin{array}{l}37.822 * * * \\
(3.29)\end{array}$ & $\begin{array}{l}8.380 * * * \\
(3.36)\end{array}$ \\
\hline$N E T \_H E D G E \_T A$ & - & $\begin{array}{l}-134.195 * * \\
(-2.28)\end{array}$ & $\begin{array}{l}-29.733 * * \\
(-2.43)\end{array}$ \\
\hline FVOLdum & - & $\begin{array}{l}-0.375 \\
(-1.43)\end{array}$ & $\begin{array}{l}-0.083 \\
(-1.41)\end{array}$ \\
\hline CRISIS_SENSITIVE & + & $\begin{array}{l}0.326 \\
(0.06)\end{array}$ & $\begin{array}{l}0.072 \\
(0.06)\end{array}$ \\
\hline Constant & & $\begin{array}{l}1.302 \\
(0.72)\end{array}$ & \\
\hline Pseudo-R2 & & $35 \%$ & \\
\hline Observations & & 148 & \\
\hline
\end{tabular}


Panel B: Probit regression with $L A R G E$ instead of TITF

Dependent variable: RECLASS

\begin{tabular}{|c|c|c|c|c|c|}
\hline VARIABLES & Predicted sign & $\begin{array}{l}\text { Coefficient } \\
(z \text {-stat })\end{array}$ & $\begin{array}{l}\text { Marginal } \\
\text { effects }\end{array}$ & $\begin{array}{l}\text { Coefficient } \\
(z \text {-stat })\end{array}$ & $\begin{array}{l}\text { Marginal } \\
\text { effects }\end{array}$ \\
\hline$L A R G E$ & $?$ & $\begin{array}{l}-0.378 \\
(-0.36)\end{array}$ & $\begin{array}{l}-0.104 \\
(-0.36)\end{array}$ & $\begin{array}{l}-0.426 \\
(-0.38)\end{array}$ & $\begin{array}{l}-0.117 \\
(-0.39)\end{array}$ \\
\hline Pre_Tierl & - & $\begin{array}{l}-16.485 \\
(-1.53)\end{array}$ & $\begin{array}{l}-4.528 * \\
(-1.67)\end{array}$ & $\begin{array}{l}-16.450 \\
(-1.51)\end{array}$ & $\begin{array}{l}-4.516 \\
(-1.64)\end{array}$ \\
\hline LARGE $x$ Pre_Tierl & $?$ & $\begin{array}{l}10.499 \\
(0.85)\end{array}$ & $\begin{array}{l}2.884 \\
(0.88)\end{array}$ & $\begin{array}{l}10.537 \\
(0.85)\end{array}$ & $\begin{array}{l}2.893 \\
(0.88)\end{array}$ \\
\hline Size & $?$ & & & $\begin{array}{l}0.015 \\
(0.13)\end{array}$ & $\begin{array}{l}0.004 \\
(0.13)\end{array}$ \\
\hline$M B$ & $?$ & $\begin{array}{l}-0.244 \\
(-1.50)\end{array}$ & $\begin{array}{l}-0.067 \\
(-1.46)\end{array}$ & $\begin{array}{l}-0.239 \\
(-1.54)\end{array}$ & $\begin{array}{l}-0.066 \\
(-1.50)\end{array}$ \\
\hline Pre_ROE & - & $\begin{array}{l}-0.336 \\
(-0.55)\end{array}$ & $\begin{array}{l}-0.092 \\
(-0.54)\end{array}$ & $\begin{array}{l}-0.342 \\
(-0.57)\end{array}$ & $\begin{array}{l}-0.094 \\
(-0.56)\end{array}$ \\
\hline Pre_HFT_TA & + & $\begin{array}{l}0.116 \\
(0.15)\end{array}$ & $\begin{array}{l}0.032 \\
(0.15)\end{array}$ & $\begin{array}{l}0.085 \\
(0.10)\end{array}$ & $\begin{array}{l}0.023 \\
(0.10)\end{array}$ \\
\hline Pre_AFS_TA & + & $\begin{array}{l}3.493 * * \\
(2.20)\end{array}$ & $\begin{array}{l}0.959 * * \\
(2.38)\end{array}$ & $\begin{array}{l}3.475 * * \\
(2.24)\end{array}$ & $\begin{array}{l}0.954 * * \\
(2.44)\end{array}$ \\
\hline GDPdum & $?$ & $\begin{array}{l}-0.552 * * \\
(-1.97)\end{array}$ & $\begin{array}{l}-0.151^{* *} \\
(-2.15)\end{array}$ & $\begin{array}{l}-0.558 * * \\
(-1.99)\end{array}$ & $\begin{array}{l}-0.153 * * \\
(-2.16)\end{array}$ \\
\hline Banks & $?$ & $\begin{array}{l}0.652 * \\
(1.77)\end{array}$ & $\begin{array}{l}0.179^{*} \\
(1.84)\end{array}$ & $\begin{array}{l}0.658^{*} \\
(1.77)\end{array}$ & $\begin{array}{l}0.181 * \\
(1.84)\end{array}$ \\
\hline Deposit & $?$ & $\begin{array}{l}0.058 \\
(0.15)\end{array}$ & $\begin{array}{l}0.016 \\
(0.15)\end{array}$ & $\begin{array}{l}0.066 \\
(0.17)\end{array}$ & $\begin{array}{l}0.018 \\
(0.17)\end{array}$ \\
\hline Legal & $?$ & $\begin{array}{l}-1.650 * * \\
(-2.08)\end{array}$ & $\begin{array}{l}-0.453 * * \\
(-2.21)\end{array}$ & $\begin{array}{l}-1.664 * * \\
(-2.05)\end{array}$ & $\begin{array}{l}-0.457 * * \\
(-2.16)\end{array}$ \\
\hline Money & $?$ & $\begin{array}{l}0.342 \\
(0.83)\end{array}$ & $\begin{array}{l}0.094 \\
(0.82)\end{array}$ & $\begin{array}{l}0.330 \\
(0.77)\end{array}$ & $\begin{array}{l}0.091 \\
(0.76)\end{array}$ \\
\hline Regional & $?$ & $\begin{array}{l}-0.118 \\
(-0.39)\end{array}$ & $\begin{array}{l}-0.032 \\
(-0.39)\end{array}$ & $\begin{array}{l}-0.112 \\
(-0.37)\end{array}$ & $\begin{array}{l}-0.031 \\
(-0.37)\end{array}$ \\
\hline Savings & $?$ & $\begin{array}{l}-0.400 \\
(-0.74)\end{array}$ & $\begin{array}{l}-0.110 \\
(-0.77)\end{array}$ & $\begin{array}{l}-0.405 \\
(-0.75)\end{array}$ & $\begin{array}{l}-0.111 \\
(-0.77)\end{array}$ \\
\hline Constant & & $\begin{array}{l}0.839 \\
(0.80)\end{array}$ & & $\begin{array}{l}0.702 \\
(0.45)\end{array}$ & \\
\hline $\begin{array}{l}\text { Pseudo-R2 } \\
\text { Observations }\end{array}$ & & $\begin{array}{l}22 \% \\
160\end{array}$ & & $\begin{array}{l}22 \% \\
160\end{array}$ & \\
\hline
\end{tabular}




\section{TABLE 7 (continued)}

The table presents probit coefficient estimates, marginal effects, and z-statistics based on robust standard errors clustered at the country level in parentheses. In Panel A, L3_HFT_TA is the proportion of Level 3 HFT assets to total assets. $L 3 \_A F S \_T A$ is the proportion of Level 3 AFS assets to total assets. NET_HEDGE_TA is the proportion of positive replacement values minus negative replacement values of hedging derivatives relative to total assets. FVOLdum is an indicator variable that equals 1 if the bank applies the FVO on its liabilities, and 0 otherwise. CRISIS_SENSITIVE the sum of mortgage-backed securities, Alt-A investments, collateralized debt obligations, and leveraged finance products, divided by total assets, with all amounts as of the beginning of 2008 .

In Panel B, we replace TITF with an indicator variable $L A R G E$ that equals 1 if total assets are above the sample median, and 0 otherwise. All other variables are defined in Table 3.

$* * *, * *$, and $*$ indicate statistical significance at the $1 \%, 5 \%$, and $10 \%$ levels (two-sided). 